\title{
COUPLED NATURE-HuMAN (CNH) SYSTEMS: GENERIC ASPECTS OF HUMAN INTERACTIONS WITH BLOOMS OF FLORIDA RED TIDE (KARENIA BREVIS) \\ AND \\ IMPLiCATIONS FOR POLICY RESPONSES
}

\author{
Porter Hoagland \\ Marine Policy Center \\ Woods Hole Oceanographic Institution \\ Woods Hole, MA 02543 \\ Phone: 1-508-289-2867 \\ Fax: 1-508-457-2184 \\ E-mail: phoagland@whoi.edu
}

July 2013

Forthcoming in: Rossini, G.P., ed. 2013. Toxins and Biologically Active Compounds from Microalgae. Vol. 2, Sec. V: Risk Management. Science Publishers, Enfield, New Hampshire.

Acknowledgements: I thank my colleagues L. Backer, A. Beet, L. Fleming, B. Garrison, G. Hitchcock, D. Jin, B. Kirkpatrick, G. Kirkpatrick, K. Kohler, R. Lazensky, Z. Li, V. Lovko, A. Reich, K. Rudge, R. Stumpf, S. Ullmann, and S. Watkins for their help with data and for their insights on human interactions with Florida red tides. A. Beet, A. Kenney, and S. Lavey provided research assistance. B. Kirkpatrick, M. Schumacher, and D. Jin provided valuable comments on an earlier draft. Any errors are my responsibility. This research was sponsored by the US National Science Foundation under NSF Grant No. 1009106 $(\mathrm{CNH})$. 


\section{Introduction}

Coupled nature-human (CNH) systems are now the focus of a growing number of interdisciplinary research programs worldwide (Liu et al. 2007a). ${ }^{1}$ As implied by the term "coupled," these systems involve interactions between nature and humans, often affecting the dynamic characteristics of each component. Natural and social scientists supported by the US National Science Foundation and other research sponsors are engaged in developing a deeper understanding of these dynamics, focusing on the linkages and feedbacks affecting the trajectories of coupled system behavior. ${ }^{2}$

Human interactions with natural hazards, such as volcanoes, earthquakes, tsunamis, major storms, floods, droughts, forest fires, tornadoes, soil erosion, mudslides, sink holes, avalanches, lightning strikes, among many others, often involve such couplings. Indeed, economists who specialize in catastrophes have long defined natural hazards as comprising a process of joint production (Russell 1970, Zeckhauser 1996). Without a human presence, a natural hazard cannot impose impacts that can be measured or felt in socio-economic or other terms. ${ }^{3}$ In some instances, humans may contribute to the occurrence of a hazard or influence its frequency, scale, intensity, or duration. Even when humans do not cause or exacerbate a hazard, they may suffer its adverse effects, and there may be actions that can be taken to mitigate them.

This chapter focuses on a specific type of hazard-human coupling relating to coastal blooms of toxic marine algae, often referred to as harmful algal blooms (HABs). Specifically, we draw examples primarily from human interactions with blooms of the toxic dinoflagellate Karenia brevis from the Gulf of Mexico. ${ }^{4}$ Humans interact with marine algae in many ways, and the great majority of such interactions are positive and beneficial. Because primary productivity drives oceanic ecosystems from the bottom up, algae provide a critical, but mostly unquantified and often unappreciated, ecosystem service to humans. Even toxic dinoflagellates such as $K$. brevis may serve a beneficial ecological role in terms of primary productivity and nutrient cycling (Vargo et al. 1987).

Where algae are concerned, harmfulness can appear in a variety of forms. When humans release macronutrients, such as compounds of nitrogen and phosphorous, into marine environments in quantities that exceed local capacities for assimilation, excessive algal production, leading eventually to eutrophic conditions characterized by hypoxia, may occur. While such situations are widely understood as harmful, we concentrate more narrowly on blooms of algal species that synthesize chemical compounds that are toxic to humans. In some- but not all and possibly not even most — cases, these HABs may be the consequence of excessive anthropogenic-sourced nutrient loadings (Anderson et al. 2002, Berg et al. 2003). Often the reasons for the occurrence of blooms of harmful algae are uncertain, or they may occur only as natural phenomena.

Several authors have begun to outline the generic aspects of nature-human couplings (Liu et al. 2007b). Many of these aspects have been adapted from the field of ecology, where the dynamic character-

\footnotetext{
${ }^{1}$ The CHANS-Net website facilitates worldwide communication of CNH research: http://chans-net.org/.

${ }^{2}$ The US National Science Foundation "crosscutting” program on the Dynamics of Coupled Natural and Human Systems (CNH) has been funding research in this area since 2001. See: http://www.nsf.gov/funding/pgm_summ. jsp? pims_id=13681.

${ }^{3}$ Strictly speaking, humans might realize "passive" benefits from a natural system that they do not use directly. Environmental economists have argued that such benefits arise due to the possibility of future use by members of the current generation (option value), the possibility of future use by members of future generations (bequest value), or because members of the current generation merely know about and appreciate such systems (existence value). If passive benefits are real, in principle they may be affected either negatively or positively by natural phenomena.

${ }^{4}$ The Florida red tide organism, Karenia brevis (C.C. Davis) (hereinafter K. brevis), was formerly called Gymnodinium breve or Ptychodiscus brevis. See the entry for K. brevis in "algaebase": http://www.algaebase.org/search/species/detail/?species_id=44330.
} 
istics of ecological systems have been studied for decades. These aspects comprise system heterogeneity, time lags, reciprocal feedbacks, thresholds, surprises, legacies, and resilience. The presence of such phenomena has implications for the stability and persistence of particular ecosystem states, leading to further potential implications for human heath and welfare. This chapter considers some salient examples of each of these aspects in the case of Florida red tides. We argue that a deeper understanding of these phenomena and how they are manifest in the case of Florida red tides may provide insights into factors that help reduce the vulnerability of human populations, thereby leading to a more sustainable coupled nature-human system.

A seminal innovation of $\mathrm{CNH}$ research is to conceptualize humans as another biological species within more broadly defined ecosystems. Another innovation is to begin to characterize actions, known as policy responses, that humans can take to control their influence on or the extent to which they experience the impacts of natural hazards. Often this broader conceptualization and the potential human responses can be characterized as a form of "ecosystem-based management." While the development of ecosystembased management arguably is still in its infancy, and its effectiveness in any particular context should be appraised critically (cf. Layzer 2008), humans are familiar with many of the institutions though which interactions with nature may take place. A critical question relates to whether humans face the right sorts of incentives to respond to natural hazards in ways that minimize the combined costs of impacts and responses.

We review first the characteristics of $K$. brevis blooms, focusing on what is known about the occurrences and effects of the blooms. Second, we sketch the dynamics of human populations that are exposed to the blooms. Third, we investigate the generic aspects of the couplings between $K$. brevis and humans along the Gulf coast of Florida. We consider some plausible, but nonexhaustive, examples of each of these aspects, and we consider their implications for the incentives that humans face to respond to the HAB hazard. Fourth, we examine an array of policy responses, and we outline an economic approach to policy selection. We finish with a subjective prognosis of the likely implementation of appropriate policy responses, given the characteristics of the hazard, the micromotives of humans, and the interactions between the two.

\section{Karenia brevis: Florida Red Tide}

Blooms of the marine dinoflagellate, Karenia brevis, also known as "Florida red tide," occur predominantly along the Gulf coast of Florida (Fig. 1) but also elsewhere throughout the Gulf of Mexico, including along the Texas coast in the western Gulf (Magaña et al. 2003). In the eastern Gulf, a bloom of $K$. brevis typically originates offshore on the west Florida shelf (WFS), a relatively shallow submerged extension of the Florida landmass. Because the WFS is known to be mainly nitrogen-limited, the mechanisms leading to bloom occurrences on the shelf are incompletely understood. K. brevis blooms occur episodically, possibly triggered or sustained by macro-nutrient fluxes from the Mississippi River system, the deposition of iron-laden atmospheric dust transported from Africa, or fluxes from other more local coastal sources, including rivers, land runoffs, or submerged groundwater discharges. Once triggered, oceanographic factors, including currents and winds, may contribute to the scale, cell densities, transport, and fate of a bloom.

The parameters governing formation, scale, intensity, movements, and duration of $K$. brevis blooms are the subject of ongoing environmental monitoring and scientific research efforts. These efforts can be tracked roughly with estimates of the funding for scientific research on and environmental monitoring of $K$. brevis, as shown in Fig. 2. Despite intensive research, it has been problematic to show any direct causal connections between nutrient loadings and bloom characteristics (Brand and Compton 2008). A range of scientific studies conclude that coastal anthropogenic nutrient loads, especially nitrogen, should have an impact on the duration and geographic extent of $K$. brevis blooms. A problem has been identifying the source of the nitrogen, and many hypotheses have emerged, including that blooms of $K$. brevis are able to adapt to utilize alternative sources of this nutrient (Vargo 2009). 
K. brevis produces powerful toxins, known as brevetoxins, that can cause morbidities and mortalities in exposed marine organisms, from zooplankton to the higher trophic levels and to humans (Backer 2009). Large fishkills are known to occur, comprising, but not restricted to, filter feeding planktivores. Even marine mammals, including the West Indian manatee, sea turtles, and birds may experience toxic effects, sometimes where there is no outward expression of the occurrence of a Florida red tide bloom (Flewelling et al. 2005). Human exposures may occur through the consumption of filter feeding shellfish, the breathing of aerosolized toxins near the coast, and, some researchers believe, through the consumption of exposed finfish (Kirkpatrick et al. 2010). The physical manifestations of a coastal bloom, including a change in water color, dead fish on the beaches, and adverse respiratory or gastro-intestinal effects, are thought to negatively affect coastal tourism (Habas and Gilbert 1975, Morgan et al. 2009), which arguably is the largest industry in Florida. Several studies have examined the public health effects (Kirkpatrick et al. 2004, Fleming et al. 2009, 2011), the incidence and costs of respiratory illnesses (Kirkpatrick et al. 2006, Hoagland et al. 2009), and losses in local restaurant and coastal tourism businesses in Florida (Adams et al. 2002, Larkin and Adams 2007; Morgan et al. 2010).

\section{Human Populations on the Florida Gulf Coast}

Humans, likely paleo- or archaic-Mississippian peoples, existed along the Florida Gulf coast for at least 12 millennia. Around 3200 years B.P., sea levels slowed to permit the coast to stabilize at near present levels, and numerous coastal shell middens are extant, particularly those created during the last two millennia by the Calusa peoples in southwest Florida, providing evidence of ongoing and extensive human habitation along the Florida Gulf coast (Widmer 1988). Although archaeologists have uncovered in these middens patterns of seasonal exploitation and switching among target species, there is little support for a hypothesis that these patterns were caused by K. brevis blooms. Certainly, coastal cultures must have been aware of $K$. brevis, as the earliest Spanish explorers noted the existence of fish kills likely caused by red tide blooms off the Tampa Bay estuary.

Beginning in the $16^{\text {th }}$ century, Spanish, French, and British colonial movements developed successive European settlements in northern Florida at St. Augustine, Pensacola, Tallahassee, and Apalachicola. In the $18^{\text {th }}$ century, Muscogee peoples, notably the Seminoles, migrated south from Georgia into the Florida peninsula under pressure from the Upper Creeks, finding only a waning Spanish presence there, and displacing or integrating with native Choctaws. For unexplained reasons, the Seminoles exhibited a very minimal presence along the coast, preferring to live near inland swamps and creeks (Widmer 1988). After Florida became a US territory in 1819, however, the US government engaged in an extensive and costly military campaign to deracinate the Seminole peoples to lands west of the Mississippi River, thereby opening the Florida territory for white settlement.

The Florida peninsula and the Gulf coast remained only very sparsely inhabited, however, until raillines began to be laid down after statehood in 1845. Much like the development of the western United States, policies facilitating the easy disposal of land, such as Florida's Internal Improvement Act (1855), led eventually to a rail network, facilitating the growth of industrial development in agriculture (cattle, citrus, sugar cane) and mining (phosphate). The railroads also began to provide tourist access to peninsular Florida; luxury hotels were built along the rail lines, and visitors could travel from the northern United States to experience the moderate climate, the wide beaches, and riverine steamboat cruises. The choice of Sarasota as a winter estate by Chicago-native Bertha Palmer in 1910 and as a winter haven for their circus by John and Charles Ringling in 1919 are seen as seminal dates in the emergence of the Florida Gulf coast as a national tourist destination.

The population dynamics for each of the 23 counties along the Florida Gulf coast is qualitatively very similar, differing only in the actual numbers of people. The dynamics are characterized by secular longterm trends of increasing populations, perhaps leveling off during the past decade (Fig. 3). Superimposed on these trends is an intra-annual surge in visitors, beginning in October and lasting through April (Fig. 
4). ${ }^{5}$ Traditionally, this surge has been characterized as comprising mainly "snow-birds," namely older visitors who may reside in Florida for extended periods during the winter months, but estimates of the snowbird population appear to be only a small part of the surge in visitors (Fig. 4). The surge can be very important economically, leading to increases in local populations by as much as 50 percent. The actual fluxes may be more complicated, involving snow-birds, sun-birds (movements of residents or snow-birds out of Florida during the summer), and shorter-term tourist visitors (Smith and House 2006). On closer inspection, local peaks in tourist visits often occur during November, March, and April, suggesting a "headand-shoulders" type of visitor surge profile.

\section{Generic Aspects of $K$. brevis-Human Interactions}

\section{System heterogeneities}

The dynamic interactions between blooms of $K$. brevis and humans are influenced by both spatial and temporal heterogeneities. Figs. 3 and 5(a) depict the nominal growth in coastal human populations over the last 80 years. The relatively small coastal populations existing at the turn of the $20^{\text {th }}$ century imply that red tide was virtually nonexistent as a "hazard" to humans at that time. The counties from Gulf to Levy along the Gulf coast still have small populations and very slow population growth rates, and red tides are an issue primarily for the important shellfish harvesting areas of the Central Gulf coast (Gulf and Franklin counties) and the Big Bend (Dixie, Levy and Citrus counties).

In contrast, the counties of the Southwest Coast, especially Collier, Lee, and Charlotte, are now exhibiting very rapid population growth rates. As seen in Figs. 3 and 5(a), counties to the north and south of the Tampa-St. Petersburg urban area, in particular, have been growing so rapidly that they are now 30 to 40 times larger than in 1930. Collier County has grown to 120 times its size in 1930. Because of this growth, the humans living in these counties now are more exposed to red tides-even if there has been little change in the occurrence of blooms. Fig. 5(b) shows the 2010 population per $2.59 \mathrm{~km}^{2}$ in US census tracts as reported by the US Bureau of Census.

Fig. 6 identifies the spatial occurrences of blooms as measured by the numbers of days that shellfish harvest areas (SHAs) were closed during 1997-2010. (The shading on the inset bar graph indicates the proportion of each SHA closed in successive years.) Fig. 6 also shows the spatial pattern of coastal resident populations across each of the 23 Florida Gulf coast counties. The figure depicts the static spatial heterogeneities comprising human populations and both the static and temporal heterogeneities comprising Florida red tides. Fig. 7 also depicts these static heterogeneities, but in a different way, using indexes for population and Florida red tides, distributed along a "straightened" coast, where each county is represented by the proportion of its beach length to the total beach length $(702 \mathrm{~km})$ of the Florida Gulf coast. Both figures clearly show how the chief Florida red tide "hazard" is located from the Tampa-St. Petersburg region southward.

\section{Time Lags}

Connections between natural conditions and human responses often go unnoticed or are difficult to perceive due to delays between the realization of a condition and its effects and to further delays between human responses and their effects (Liu et al. 2007a). The relationship between the contamination of shellfish with brevetoxins and subsequent illnesses due to human neurotoxic shellfish poisoning (NSP) when the shellfish are consumed is well understood, and the respiratory reactions of beach-goers to aerosolized brevetoxins is almost immediate. The human response to the former involves the closure of shellfish beds, according to clear rules approved through the US Food and Drug Administration's National Shellfish Sanitation Program and Florida laws (Faris et al. 2013). Fig. 8 depicts the temporal distribution of shellfish harvest area closures in the southwest region between Pinellas and Lee counties. The human response to

\footnotetext{
${ }^{5}$ These data were made available through Smith Travel Research's SHARE Center, which compiles data nationwide on hotel and motel occupancy rates and rental rates (STR 2012).
} 
aerosolized brevetoxins involves leaving (or avoiding) the coast and visiting outpatient facilities or, in extreme cases, hospital emergency departments.

In his review of the many extant hypotheses for K. brevis blooms, Vargo (2009) argues that benthic fluxes, especially submarine groundwater and springs, containing anthropogenic nutrients, including agricultural and lawn fertilizer treatments and deposited atmospheric nitrogen, could be responsible for their initiation, growth, and maintenance. In the past, the absence of scientific sampling programs to measure benthic fluxes on the west Florida shelf meant that we could not implicate such fluxes conclusively in Florida red tide blooms. Recent research relying on the tracking of radium isotopes, however, finds that submarine groundwater discharges (SGDs) are an important source of nutrients into the Tampa Bay and the Caloosahatchee River estuaries (Swarzenski et al. 2007; Charette et al. 2013). Further, Charette et al. (2013) find that SGD is highly enriched in nutrients, especially the labile form of nitrogen found in ammonium, making it potentially important as a source of nutrient supply to blooms of both macroalgae and Florida red tides in the Caloosahatchee River estuary, particularly during periods of drought.

This research has begun to clarify the relationships between anthropogenic nutrient releases, benthic fluxes, and bloom formation, and Florida red tide maintenance and growth on the west Florida Shelf is now thought to depend in part upon nutrients supplied by SGD (Smith and Swarzenski 2012). In turn, increased understanding of nutrient fluxes may help humans understand the potential effectiveness of policy responses, such as the enactment and enforcement of municipal ordinances to control the timing and quantities of lawn fertilizer applications (Fig. 9). To date, however, whether such policies can be deemed truly effective remains indeterminate, largely because humans are either unaware of the existence of the policies, uninformed of their purposes, or they do not fertilize their lawns (Scheller et al. 2013). Consequently, there may be multiple lags in the system, occurring between physical forcings, the occurrence of blooms, and realizations of impacts as well as among effective human responses and the physical forcings.

\section{Reciprocal feedbacks}

Reciprocal feedbacks comprise interactions between nature and humans through which each may influence the other, leading to changes in the coupled system that may represent improvements or degradations in natural conditions, implying net benefits or costs from the human perspective (Fig. 10). Conceptually, a state of nature is realized in the form of a Florida red tide bloom. Depending upon its location, scale, toxicity, or duration, humans may be impacted by the bloom, representing the first type of feedback (nature to humans). Humans may react to the impact in a variety of ways, from actions that are merely responsive, such as through closures of shellfish harvesting areas or the seeking of medical treatments, to actions that attempt to prevent, control, or mitigate the characteristics of blooms (Sengco 2009). The latter types of actions (known in the field as "PCM" actions) represent a second type of feedback (humans to nature). Given large uncertainties about bloom formation and fate, feedbacks of the second type may vary widely in terms of their effectiveness.

An early example concerns the efforts by the US Fish and Wildlife Service to control a Florida red tide bloom off the coast of Pinellas County (near the Tampa/St. Petersburg urban area) during the fall of 1957 (Rounsefell and Evans 1958). The bloom occurred near shore, stretching about $50 \mathrm{~km}$ along the coast with cell densities of up to $10 \times 10^{6}$ cells per liter, causing respiratory pathologies in exposed humans. Over the two months from September to October in that year, the Service dispersed across a $41 \mathrm{~km}^{2}$ area about $23 \mathrm{~kg} / \mathrm{ha}$ of $\mathrm{CuSO}_{4}$, a known algaecide, from crop-dusting aircraft and from burlap bags towed behind workboats. This treatment led to immediate declines in $K$. brevis cell densities, removing the algae completely in some locations. Within two weeks, however, the bloom had re-established itself in 40 percent of the treatment area, albeit at lower cell densities, suggesting that the control method had been only temporarily effective. Its limited effectiveness, in combination with the large costs of $\mathrm{CuSO}_{4}$ dispersal (about $\$ 5,000 / \mathrm{km}$ in today's dollars) and the uncertainties associated with the likely deleterious effects on other components of the ecosystem, has precluded any subsequent use of the method. 


\section{Thresholds}

Thresholds comprise transitions between states of nature, such as the occurrence of a $K$. brevis bloom (Walker and Myers 2004). Transitions can be either reversible or irreversible. Where underlying environmental or human characteristics are changing, such as through increasing levels of anthropogenic nutrient releases, the ability of a coupled system to remain in a pre-existing state may be compromised. If so, the system is said to have lost resilience, which is the ability to maintain ecological processes and structures in response to disturbances. In some cases, a system may lose resilience imperceptibly until a threshold is crossed, causing a perceived change in ecosystem state and leading to a degraded system.

Brand and Compton (2007) develop a convincing, if circumstantial, case for the existence of a changed ecological state along the southwest coast of Florida. These authors examine water monitoring data to identify K. brevis compiled by the Florida Fish and Wildlife Research Institute (FWRI) over several decades, beginning in the 1950s. The data are the consequence of opportunistic sampling, taking place only after blooms had been reported. As a result, as a characterization of a change in regime, the data are flawed, because they were collected neither systematically nor randomly. Due to these flaws, the FWRI data likely overestimate the average spatial and temporal abundances of K. brevis. Simply put, if more blooms have been observed in recent years relative to earlier years, because humans are either more aware or searching more actively for them, and if more sampling occurred in response to these observations, then the data might be misinterpreted as a change in regime to one in which Florida red tides occur more frequently.

Nevertheless, after attempting to adjust for sampling bias, the authors show that in comparing the period 1994-2002 to an earlier period, 1954-1963, K. brevis was 13 to 18 times more abundant, the blooms extended further offshore, and they occurred at higher concentrations during more months of the year (Brand and Compton 2007). The authors argue that the apparent increase in K. brevis biomass is the consequence of an increased availability of nutrients, and, after examining all of the possible sources of nutrients, they conclude that the increased human populations and related activities represent the most plausible source. These nutrients, while derived from anthropogenic sources, likely flow from rivers, non-point sources, and groundwater, and they become stored in a "nutrient pool," comprising sediments and increased biomass of both macroalgae and seagrasses. In particular, the authors argue that the construction of a canal between Lake Okeechobee and Lake Hicpochee greatly enlarged the watershed draining into the Caloosahatchee River, which empties into the Charlotte Harbor estuary near Ft. Myers on the Florida southwest coast. Although the canal, built in 1920 and expanded in 1930 and 1960, pre-dates the apparent observed increases in $K$. brevis abundance, the extensive agricultural development in the enlarged watershed could provide a significant source of nutrients for the more recent bloom period.

The possibility of the crossing of a threshold in southwest Florida, leading to an increased abundance of $K$. brevis and more frequent Florida red tides, has been the subject of scientific debate, in part because blooms do not occur every year, and, when they do occur, their timing is sporadic. Further, the earliest evidence of Florida red tides, reported in 1542 by the Spanish explorer Alvar Nunez Cabeza de Vaca, concerns the "chronicling" of fish kills by local indigenous peoples, likely the Calusa (Steidinger et al. 1998). While it is impossible to identify the frequency of blooms or other bloom characteristics from this report, the notion of recording significant events in chronological order suggests that Florida red tides were sporadic — but not necessarily extraordinary — events in an era that predates significant anthropogenic contributions to the supply of coastal macronutrients.

It is likely that other factors, especially ecological processes, such as algal species competition, and oceanographic processes, such as currents, influence the timing and occurrence of Florida red tide blooms. Further, there is still a question of potential reversibility, should anthropogenic nutrient flows be reduced. According to Brand and Compton (2007), however, the presence now of a nutrient "pool" that could serve as a source of supply of significant levels of nutrients suggests that a threshold has been crossed, and reversibility is less likely in the near term. 


\section{Surprises}

Surprises are unexpected outcomes of complex nature-human interactions (Liu et al. 2007b). They may arise as the consequence of uncertainties about the dynamic characteristics of either natural phenomena or human demographics or because of incomplete knowledge about how nature and humans are linked. Often the complexity of the linked system results in surprises because of the difficulty of predicting cause and effect in a nonlinear system. Florida red tide surprises include, among others, epizootic mortalities of marine mammals in the apparent absence of high concentrations of $K$. brevis (Flewelling et al. 2005); appearance of gastro-intestinal illnesses in the absence of the consumption of shellfish, suggesting that finfish are a potential vector (Kirkpatrick et al. 2010, Hoagland et al. 2013); and high-density K. brevis blooms that do not exhibit high levels of toxicity.

During the winter of 2012-2013, Sarasota Bay experienced high levels of Florida red tide, but few of the effects associated with toxicity were manifest. ${ }^{6}$ Shellfish beds were closed, as required by law, but there were no obvious fish kills and few complaints about respiratory problems. The bloom was considered to be part of a larger bloom extending down the coast to Charlotte, Lee, and Collier counties, where the bloom exhibited some of the classic evidence of toxicity, including a record number of mortalities of the West Indian manatee. This wide variation in levels of toxicity was clearly a surprise associated with the bloom.

Recent research suggests that the toxicity of Florida red tide may be a consequence of both N- and Plimitations (Hardison et al. 2012, 2013). ${ }^{7}$ While there may be variability among different strains of $K$. brevis, P-limitation may lead to twice as much toxin per cell as N-limitation. According to the carbon:nutrient balance (CNB) hypothesis (Bryant et al. 1983), which may apply also to vascular plants, as algal growth slows in response to nutrient limits, cells incorporate more fixed carbon into mechanisms for defense. In K. brevis, defense mechanisms would comprise brevetoxins, serving an important anti-grazing function, ensuring that $K$. brevis cells are protected when they are unable to grow at normal rates. As grazing is reduced, nutrient recycling may be impeded, leading to further nutrient limitations, creating a positive feedback that may lead to successively higher levels of bloom toxicity (Hardison et al. 2013). When brevetoxins are released as the cells lyse after death, the toxins enter the marine environment, adsorbing onto seagrasses, accumulating in shellfish, and aerosolizing in the atmosphere.

Variation in cell toxicity has obvious implications for the protection of cells, but it also may lead to higher-order impacts on finfish stocks, protected species (including marine mammals and sea turtles), levels of shellfish toxicities, and human respiratory health. Because shellfish sanitation focuses on cell counts and not on cell toxicity, P-limitation could lead to instances of the occurrence of unhealthy levels of toxicity that are masked by low cell densities. As a consequence, NSP illnesses arguably could occur when shellfish harvest areas remain open (cf., Faris et al. 2013). Further, policy responses that focus on reductions of anthropogenic nutrients in near coastal waters may need to be reconsidered, if blooms are made more toxic as pollution is reduced. The complexity of the patterns of nutrient fluxes from runoffs, river flows, submerged groundwater discharges, aeolian dust, among others, implies that it may be difficult to predict nutrient distributions and consequently the distributions of bloom toxicity, thereby leading to more surprises.

\footnotetext{
${ }^{6}$ This observation is mainly anecdotal, based upon observations of local restaurateurs, reports in the press (e.g., Anderson 2013), and the absence of dead fish on the northernmost Sarasota beaches. Whether this is a true "surprise" may be debated, as the NOAA Harmful Algal Bloom Operational Forecast System (HAB-OFS) reported for January 3, 2013 (2013-001) that "[a]longshore Sarasota County, samples indicate K. brevis concentrations may have decreased to a range of not present to 'low b' concentrations where 'very low a' to 'high' concentrations were previously identified" (tidesandcurrents.noaa.gov/hab/ bulletins.html). One hypothesis is that the passing of Superstorm Sandy pushed the bloom to the south.

${ }^{7}$ Other environmental factors, including the amount of sunlight, may affect the toxicity of $K$. brevis (Schaeffer et al. 2009).
} 


\section{Legacies}

Legacies involve the persistence of coupled nature-human interactions over extended periods of time. Importantly, the duration and impact of a legacy may vary, and legacies may be reversible due to natural forces or human actions. Along the Florida Gulf coast, human legacies comprise the secular trends of population increases; human coastal developments, including hotels, condominium complexes, and residences; human dredging of canals and filling of wetlands to create waterfront residences and access; and increases in the supply of macro-nutrients to rivers, groundwater, and estuaries as the consequence of agriculture, phosphate mining, human waste treatments, and the fertilizing of lawns.

The large shellfish middens created by the Calusa peoples along the southwest coast between 500 and $1750 \mathrm{AD}$ are good examples of legacies, suggesting that early human cultures, possibly as early as 3500 $\mathrm{BC}$, relying upon filter-feeding shellfish as a central source of protein, were able to coexist for centuries with blooms of Florida red tides. Unfortunately, no evidence has been found of the potential presence of red tide in the middens), so it is presently not possible to confirm a linkage between humans and red tides during that period. Because $K$. brevis has no thick cell wall to be preserved or fossilized, evidence of its historical presence would need to rely upon advances in the identification of brevetoxin breakdown products (Mendoza et al. 2008).

The West Indian manatee (Trichecus manatus) provides an example of a modern legacy. Since the mid-1970s, the manatee has been listed as an endangered marine mammal at both the federal and state levels. The manatee grazes primarily on submerged vegetation in rivers and estuaries, consuming large quantities of seagrasses and other freshwater or marine plants each day. The manatee prefers warm water (typically greater than $20^{\circ} \mathrm{C}$ ), and it is capable of traveling for long distances up rivers and along the coast. Currently, the Florida manatee numbers approximately 5,000 individuals comprising a "metapopulation," distributed among three spatially distinct stocks found in the coastal waters of the Florida east coast, the southwest coast, and the panhandle.

When Florida coastal waters cool during the winter, manatees congregate at locations of the warm water effluents emanating from natural springs and electric power plant cooling water outfalls (Laist and Reynolds 2005a, 2005b). Under extreme conditions, manatees that cannot access sources of warm water may experience cold stress, leading to morbidities and mortalities. Sources of warm water have been critical in allowing the manatee population to begin to recover from its endangered status. In recent years, several older power plants on both the east and west coasts have been either modernized or scheduled to be closed as a consequence of age and the high cost of operations. Modernization would involve reducing thermal effluents, which is regarded as a general form of pollution. Either option would reduce the potential thermal "habitat" available for manatees. Several alternatives have been considered and even tried, including warming protected waters artificially, using solar or fossil fuel power, and restoring degraded natural springs. These options are controversial, as it is unknown how the manatee stocks will respond to changed patterns and volumes of thermal effluents. Consequently, a "legacy" of thermal effluent habitat for manatees faces an uncertain future (Laist et al. 2013).

Scientists have begun to hypothesize linkages between the warm water effluents and Florida red tides in their combined effects on the health of manatees (Bossart 1998). When red tide blooms occur near warm water springs or outfalls during the winter months, manatees are unable or unwilling to evade the blooms because of their aversion to cold water. Manatees apparently become adversely affected by red tide through breathing the aerosols and consuming submerged vegetation to which toxins adsorb. Further, exposure to cold water may lead to immunosuppression, increasing the likelihood of the susceptibility to red tide toxins. Consequently, a trade-off exists between the human legacy of thermal effluents and the increased risks of the exposure of manatees to red tides.

\section{Resilience and vulnerability}

Resilience refers to the ability of a coupled nature-human system to withstand perturbations or to absorb shocks such that existing ecological structures and processes and human activities are maintained (Adger 
et al. 2005). When applied to a coupled nature-human system, resiliency may imply adaptation in the sense of learning about environmental changes - either natural or human caused - and reacting in a manner that mitigates potential adverse impacts. The related concept of "vulnerability" is roughly opposite in meaning to resiliency, refering to the susceptibility of a system to adverse events and an inability to cope with or adapt to these events (Turner et al. 2003).

Along the Florida Gulf coast, there are a number of natural hazards, including hurricanes, thunderstorms, storm surges and flooding, coastal erosion, sink holes, wildfires, drought, heat waves, winter frosts, congregations of insects, algal blooms, and hypoxia, among others. Hurricanes are probably the most well-known and likely lead to the widest range and highest levels of economic impacts, depending upon a storm's path and its severity. Hurricanes also are linked to many of the other hazards, including storm surges, flooding, and coastal erosion. Even Florida red tides have been hypothesized to be influenced by the increased nutrient flows following the high levels of precipitation during a hurricane event (Hu et al. 2006). Studies often are made of the economic impacts of such hazards, although these studies tend to focus on the local level, and they tend to ignore offsetting factors, such as insurance and disaster assistance. Given the secular pattern of increasing population growth along the Florida Gulf coast, one might conclude that the nature-human system is highly resilient, even with respect to hurricanes as one of the most significant natural hazards.

Strobl (2008) examined the resilience of US coastal populations, including those in Florida, to hurricane damages, as measured by disruptions to income flows. The worst hurricane-related damages result from the destruction of housing, capital stock, and crops, the contamination of freshwater with salt, and widespread flooding, although these damages tend to be idiosyncratic and nonuniform across localities. Importantly, after a storm, insurance claims, disaster assistance, clean-ups, and recovery counteract the immediate economic effects of storm damages. Analyzing data on hurricane wind speeds and annual census tract data, the author confirmed that areas with higher densities of residents and firms were affected more seriously by hurricanes. Observed decreases in measures of long-term economic productivity, however, were mainly the consequence of wealthy residents leaving areas where dramatic damages had occurred. The author concluded that, while severe storms can have an effect on the municipality or county of landfall, the economic impacts of hurricanes were insignificant at the state or national level. Consequently, resilience might be understood as a function of geographic scale, with local regions likely more vulnerable than those of higher order.

It is even more difficult to make conclusions about the vulnerability of human populations to other hazards, such as Florida red tides. Several studies have shown impacts at the local level (Adams et al. 2002; Larkin and Adams 2007; Hoagland et al. 2009; Morgan et al. 2009, 2010), but these impacts tend to be short-lived and regionally constrained. Further, some types of economic impacts may be offset at local or regional levels. Concerns have been expressed for years about the potential impacts on Florida tourism of blooms of red tide. Unfortunately, the available data on tourist flows is a short panel, going back only about 25 years, rendering it difficult, but not inconceivable, to examine potential inter-annual variations tied to Florida red tides across counties. Assessment of such data would need to control for other influences, including weather and economic conditions.

Fig. 11 depicts the result of a simple model for Sarasota County that models tourism, as measured by the percentage occupancy in hotels and motels, as a lagged function of the occurrence of Florida red tides (months of red tide per year from water monitoring data compiled by the Florida Fish and Wildlife Research Institute) in the previous year, while controlling for changes in the stock of rooms and in real per capita gross domestic product (P.H., unpublished data). This model concludes that fluxes in the tourism component of Florida's population likely is unrelated to the occurrence of Florida red tide blooms, suggesting that tourism is resilient to the hazard. The data appear to show a secular decline in percentage occupancy over the series, although the time frame is short, and it is significantly affected by the supply of hotel and motel rooms (which have increased by almost 40 percent from 1987-2012), and the dampening effect on tourism of several recessionary periods. Further research might usefully examine how tourism 
fluxes change in adjacent counties, and thereby help to clarify the potential resilience of the human-nature system in the context of Florida red tides.

\section{Policy Responses}

In Fig. 12, we present the process by which Florida red tide becomes a natural hazard. There are several points at which human policy actions (here we use the term "policy responses" or merely "responses") may be implemented in an attempt to mitigate the hazard. These points are indicated with arrows that identify the relevant responses. We take a broad view of the term "policy" to comprise both collective and individual actions and programs.

Policy responses, if effective, are likely to lead to reductions in economic damages, constituting economic benefits. This effect is represented in the stylized example of Fig. 13, where MB stands for the marginal benefits of implementing a policy response. In the general case, increasing levels of response lead to ever greater benefits, but there may be diminishing returns to each additional level of response, in terms of reducing any hazard-related damages. As a result, the marginal benefits are declining with the level of policy response. Implementing a policy response is costly, and, in the general case, these costs increase at an increasing rate with the level of policy response. Consequently, the marginal costs (MC) of a policy response also are increasing. From an economic perspective, society (and firms and individuals) should seek an optimal level of policy response, which occurs where $\mathrm{MB}=\mathrm{MC}$ or $\mathrm{P}^{*}$ in the figure. ${ }^{8}$ At $\mathrm{P}^{*}$, each additional dollar spent responding to the hazard just yields a dollar of reductions in damages.

What makes the management of Florida red tides challenging is that society's goals may not coincide neatly with those of firms or individuals. Consequently, some groups may bear the burdens of policy responses more than others. For example, even though tourists would prefer to see fewer blooms of Florida red tides, leading perhaps to cleaner beaches and lower levels of aerosolized toxins, it may be costly for farms to remove cropland from production, phosphate mines to reduce their rates of extraction, and homeowners to stop applying lawn fertilizer, where they perceive negative effects on resource production or property values.

Further, in the real world, there may be a wide range of ideas about how best to respond to a natural hazard, such as Florida red tide. Each of these responses likely varies in the degree to which it is effective in mitigating the hazard, and there may be high levels of uncertainty about this effectiveness. Some responses may be deemed unacceptable because of side-effects that impact humans, nature, or the coupled system. Some responses may be complementary, implying that they should be used in combination, and some responses may be competing, reducing the effectiveness of other responses. We consider some of these issues below, using an economic cost-effectiveness framework. While such an approach appears logical, we recognize that insufficient experience with a response or the lack of knowledge about the effectiveness of a response may lead to a less rational muddling-through of feasible approaches.

We list several of the alternative policy responses for brevetoxin-induced illnesses in Table 1 . We classify these responses crudely from short- to long-term: alerts, shellfish harvesting area closures, publications (research, monitoring, and forecasting), pollution controls, and education. Alerts and publications involve providing the public with information that can be used to minimize exposure to brevetoxins, mainly through changes in their behavior, such as by staying indoors or by choosing to visit a different beach. Scientific research, monitoring, forecasting, and education are longer-term activities that contribute to the public's knowledge about the location, timing, severity, and duration of blooms; possible an-

\footnotetext{
${ }^{8}$ It is possible that MC $>$ MB for all levels of a policy response, in which case it would not make sense to implement the response. Large-scale applications of $\mathrm{CuSO}_{4}$ in the marine environment might be a good example of this. It is also possible that $\mathrm{MB}>\mathrm{MC}$ for all levels of policy response, making it optimal to remove the hazard entirely. Such a situation would appear impossible for Florida red tide, although it might be achieved for constrained environments for short periods of time, such as through the spraying of clay flocculants over the surface of a small waterbody. In principle, it is possible to implement more than one policy response (see the following discussion).
} 
thropogenic factors contributing to bloom formation; and appropriate policy responses or behavioral adaptations. For each of these classes of HAB response, we tabulate also the agency responsible for carrying out the policy, the target audience, the potential effect, and the qualitative nature of the direct costs of the policy.

Table 1: Policy Responses to Mitigate Respiratory Impacts from Aerosolized Brevetoxins

\begin{tabular}{|c|c|c|c|c|}
\hline $\begin{array}{l}\text { POLICY RE- } \\
\text { SPONSE } \\
\text { (ACTUAL OR } \\
\text { PROPOSED) }\end{array}$ & $\begin{array}{c}\text { RESPONSIBLE } \\
\text { AGENCY }\end{array}$ & $\begin{array}{l}\text { TARGET AUDI- } \\
\text { ENCE }\end{array}$ & $\begin{array}{c}\text { POTENTIAL EF- } \\
\text { FECT }\end{array}$ & $\begin{array}{c}\text { TYPES OF DIRECT } \\
\text { COSTS }\end{array}$ \\
\hline $\begin{array}{l}\text { Beach Conditions } \\
\text { Report }\end{array}$ & $\begin{array}{l}\text { Local; Mote } \\
\text { Marine Labor- } \\
\text { atory }\end{array}$ & $\begin{array}{l}\text { Residents; Tour- } \\
\text { ists }\end{array}$ & $\begin{array}{l}\text { Reductions in } \\
\text { beach visits dur- } \\
\text { ing blooms }\end{array}$ & $\begin{array}{l}\text { Cost of equipment, } \\
\text { recruitment/retention } \\
\text { of beach monitors, } \\
\text { data compilation, } \\
\text { and reporting }\end{array}$ \\
\hline $\begin{array}{l}\text { "Breathe Easy" } \\
\text { Campaign with } \\
\text { Signage \& Poison } \\
\text { Information Hot- } \\
\text { line }\end{array}$ & $\begin{array}{l}\text { State Depart- } \\
\text { ment of } \\
\text { Health; Local; } \\
\text { Mote Marine; } \\
\text { University of } \\
\text { Miami; } \\
\text { START }\end{array}$ & $\begin{array}{l}\text { Residents; Tour- } \\
\text { ists; Healthcare } \\
\text { providers }\end{array}$ & $\begin{array}{l}\text { Reductions in } \\
\text { beach visits dur- } \\
\text { ing blooms }\end{array}$ & $\begin{array}{l}\text { Costs of develop- } \\
\text { ment and evaluation } \\
\text { of \& erecting sign- } \\
\text { age and hotline op- } \\
\text { erations }\end{array}$ \\
\hline $\begin{array}{l}\text { Aquatic Toxins } \\
\text { Hotline }\end{array}$ & $\begin{array}{l}\text { Federal State; } \\
\text { Private; uni- } \\
\text { versity }\end{array}$ & $\begin{array}{l}\text { Residents; Tour- } \\
\text { ists; Healthcare } \\
\text { providers }\end{array}$ & $\begin{array}{l}\text { Reductions in } \\
\text { beach visits dur- } \\
\text { ing blooms }\end{array}$ & $\begin{array}{l}\text { Costs of } 800 \text { num- } \\
\text { ber, poison infor- } \\
\text { mation specialist, } \\
\text { training, evaluation, } \\
\text { data compilation and } \\
\text { hotline operations }\end{array}$ \\
\hline $\begin{array}{l}\text { Public service } \\
\text { announcements }\end{array}$ & $\begin{array}{l}\text { Federal; State; } \\
\text { Local; Private; } \\
\text { university }\end{array}$ & $\begin{array}{l}\text { Residents; Tour- } \\
\text { ists }\end{array}$ & $\begin{array}{l}\text { Reductions in } \\
\text { beach visits dur- } \\
\text { ing blooms }\end{array}$ & $\begin{array}{l}\text { Cost of development } \\
\text { and evaluation of, } \\
\text { information organi- } \\
\text { zation and making } \\
\text { announcements }\end{array}$ \\
\hline Media coverage & $\begin{array}{l}\text { Private; uni- } \\
\text { versity; state; } \\
\text { federal }\end{array}$ & $\begin{array}{l}\text { Residents; Tour- } \\
\text { ists }\end{array}$ & $\begin{array}{l}\text { Lower numbers } \\
\text { of tourist visits; } \\
\text { reductions in } \\
\text { beach visits dur- } \\
\text { ing blooms }\end{array}$ & $\begin{array}{l}\text { Cost of information } \\
\text { gathering and report- } \\
\text { ing }\end{array}$ \\
\hline $\begin{array}{l}\text { FWC Weekly } \\
\text { Bulletin }\end{array}$ & State & $\begin{array}{l}\text { Scientific com- } \\
\text { munity; Natural } \\
\text { resource man- } \\
\text { agers; Locali- } \\
\text { ties; Residents }\end{array}$ & $\begin{array}{l}\text { Increased ability } \\
\text { to forecast } \\
\text { blooms; ad- } \\
\text { vanced warnings } \\
\text { of blooms; lower } \\
\text { numbers of tour- } \\
\text { ist visits during } \\
\text { blooms }\end{array}$ & $\begin{array}{l}\text { Costs to volunteers } \\
\text { of sampling and } \\
\text { monitoring and to } \\
\text { FWC staff for data } \\
\text { evaluation and com- } \\
\text { pilation }\end{array}$ \\
\hline
\end{tabular}




\begin{tabular}{|c|c|c|c|c|}
\hline $\begin{array}{l}\text { POLICY RE- } \\
\text { SPONSE } \\
\text { (ACTUAL OR } \\
\text { PROPOSED) }\end{array}$ & $\begin{array}{c}\text { RESPONSIBLE } \\
\text { AGENCY }\end{array}$ & $\begin{array}{c}\text { TARGET AUDI- } \\
\text { ENCE }\end{array}$ & $\begin{array}{c}\text { Potential EF- } \\
\text { FECT }\end{array}$ & $\begin{array}{c}\text { TYPES OF DIRECT } \\
\text { COSTS }\end{array}$ \\
\hline $\begin{array}{l}\text { Scientific or prac- } \\
\text { titioner presenta- } \\
\text { tions to the gen- } \\
\text { eral public }\end{array}$ & $\begin{array}{l}\text { Private; uni- } \\
\text { versity }\end{array}$ & $\begin{array}{l}\text { Residents; Tour- } \\
\text { ists }\end{array}$ & $\begin{array}{l}\text { Lower numbers } \\
\text { of tourist visits to } \\
\text { beach during } \\
\text { blooms; no de- } \\
\text { crease in safe } \\
\text { seafood con- } \\
\text { sumption during } \\
\text { blooms; decrease } \\
\text { in unsafe seafood } \\
\text { consumption dur- } \\
\text { ing blooms; }\end{array}$ & $\begin{array}{l}\text { Costs of data prepa- } \\
\text { ration and analysis } \\
\text { and presentation (see } \\
\text { Scientific Research) } \\
\text { as well as creation } \\
\text { and dissemination }\end{array}$ \\
\hline $\begin{array}{l}\text { Scientific or prac- } \\
\text { titioner presenta- } \\
\text { tions to the medi- } \\
\text { cal community }\end{array}$ & $\begin{array}{l}\text { Private; uni- } \\
\text { versity }\end{array}$ & $\begin{array}{l}\text { Doctors; Nurs- } \\
\text { es; Medical ad- } \\
\text { ministrators }\end{array}$ & $\begin{array}{l}\text { Increased effi- } \\
\text { ciency in recog- } \\
\text { nition, reporting, } \\
\text { and appropriate } \\
\text { treatment of ad- } \\
\text { verse health ef- } \\
\text { fects }\end{array}$ & $\begin{array}{l}\text { Cost of education, } \\
\text { creation and evalua- } \\
\text { tion of materials, } \\
\text { dissemination }\end{array}$ \\
\hline $\begin{array}{l}\text { Scientific Re- } \\
\text { search }\end{array}$ & $\begin{array}{l}\text { Private; State; } \\
\text { Federal; uni- } \\
\text { versity }\end{array}$ & $\begin{array}{l}\text { Scientific } \\
\text { Community; } \\
\text { Government }\end{array}$ & $\begin{array}{l}\text { Increased ability } \\
\text { to forecast } \\
\text { blooms; ad- } \\
\text { vanced warnings } \\
\text { of blooms; in- } \\
\text { creased recogni- } \\
\text { tion of acute and } \\
\text { chronic health } \\
\text { effects and their } \\
\text { prevention and } \\
\text { treatment }\end{array}$ & $\begin{array}{l}\text { Cost of conducting } \\
\text { scientific research, } \\
\text { including research } \\
\text { cruises; instrument } \\
\text { deployments; lab } \\
\text { operations; animal } \\
\text { model experimenta- } \\
\text { tion; human subject } \\
\text { recruitment and } \\
\text { maintenance of co- } \\
\text { horts; compilation } \\
\text { and analysis of data; } \\
\text { and publication of } \\
\text { results }\end{array}$ \\
\hline HAB Monitoring & $\begin{array}{l}\text { Private; State; } \\
\text { Federal }\end{array}$ & Government & $\begin{array}{l}\text { Enhanced ability } \\
\text { to track the dura- } \\
\text { tion and extent of } \\
\text { blooms }\end{array}$ & $\begin{array}{l}\text { Costs of sampling } \\
\text { and monitoring }\end{array}$ \\
\hline HAB Forecasting & Federal & Government & $\begin{array}{l}\text { Increased ability } \\
\text { to forecast } \\
\text { blooms; ad- } \\
\text { vanced warnings } \\
\text { of blooms }\end{array}$ & $\begin{array}{l}\text { Cost of integrating } \\
\text { with monitoring in- } \\
\text { frastructure, new } \\
\text { infrastructure; mod- } \\
\text { eling, operating the } \\
\text { forecast system }\end{array}$ \\
\hline
\end{tabular}




\begin{tabular}{|c|c|c|c|c|}
\hline $\begin{array}{l}\text { POLICY RE- } \\
\text { SPONSE } \\
\text { (ACTUAL OR } \\
\text { PROPOSED) }\end{array}$ & $\begin{array}{c}\text { RESPONSIBLE } \\
\text { AGENCY }\end{array}$ & $\begin{array}{c}\text { TARGET AUDI- } \\
\text { ENCE }\end{array}$ & $\begin{array}{c}\text { Potential EF- } \\
\text { FECT }\end{array}$ & $\begin{array}{c}\text { TYPES OF DIRECT } \\
\text { COSTS }\end{array}$ \\
\hline $\begin{array}{l}\text { Lawn Fertilizer } \\
\text { Controls }\end{array}$ & Local & Homeowners & $\begin{array}{l}\text { Possible reduc- } \\
\text { tion in nutrients } \\
\text { leading to a re- } \\
\text { duction in the } \\
\text { frequency and } \\
\text { duration of } K \text {. } \\
\text { brevis and other } \\
\text { HAB blooms }\end{array}$ & $\begin{array}{l}\text { Reductions in prop- } \\
\text { erty values due to } \\
\text { less attractive lawns }\end{array}$ \\
\hline Nutrient Pledges & Local & Homeowners & $\begin{array}{l}\text { Possible reduc- } \\
\text { tion in nutrients } \\
\text { leading to a re- } \\
\text { duction in the } \\
\text { frequency and } \\
\text { duration of } K \text {. } \\
\text { brevis and other } \\
\text { HAB blooms }\end{array}$ & $\begin{array}{l}\text { Reductions in prop- } \\
\text { erty values due to } \\
\text { less attractive lawns }\end{array}$ \\
\hline $\begin{array}{l}\text { Wastewater } \\
\text { Treatment }\end{array}$ & Federal; Local & $\begin{array}{l}\text { Homeowners; } \\
\text { Businesses }\end{array}$ & $\begin{array}{l}\text { Depends upon } \\
\text { level of treat- } \\
\text { ment; possible } \\
\text { reduction in nu- } \\
\text { trients leading to } \\
\text { a reduction in the } \\
\text { frequency and } \\
\text { duration of } K \text {. } \\
\text { brevis and other } \\
\text { HAB blooms }\end{array}$ & $\begin{array}{l}\text { Capital and operat- } \\
\text { ing costs of MWTPs }\end{array}$ \\
\hline $\begin{array}{l}\text { NIEHS AMBI- } \\
\text { ENT Curriculum }\end{array}$ & $\begin{array}{l}\text { Mote Marine } \\
\text { Laboratory; } \\
\text { University of } \\
\text { Miami; Pub- } \\
\text { lic School } \\
\text { System }\end{array}$ & $\begin{array}{l}\text { Children \& } \\
\text { Teachers }\end{array}$ & $\begin{array}{l}\text { Educate the resi- } \\
\text { dent public on } \\
\text { the hazards of } K \text {. } \\
\text { brevis blooms; } \\
\text { reductions in } \\
\text { beach visits }\end{array}$ & $\begin{array}{l}\text { Cost of education } \\
\text { programs develop- } \\
\text { ment, evaluation and } \\
\text { dissemination }\end{array}$ \\
\hline
\end{tabular}

\section{Policies to prevent blooms}

If Florida red tides are the consequence of anthropogenic releases of nutrients into the marine environment, then implementing policies such as erosion controls, holding ponds for rainwater runoff near urban developments, septic system upgrades, best practices for residential fertilizer applications, or the construction of tertiary municipal waste treatment plants might reduce the likelihood or severity of the blooms. Environmental and economic research suggests a wide range of potential policies. Spatially explicit models of nutrient loading across watersheds have been developed to identify socially optimal policies to reduce nutrient pollution throughout a large region to minimize the costs associated with control measures (Roberts et al. 2008, Feng et al. 2009). A seminal study of this kind was conducted by Valiela et al. (1997) in the Waquoit Bay watershed on Cape Cod, Massachusetts. These authors recommended the conservation of land with accreting natural vegetation, setbacks of septic systems within $200 \mathrm{~m}$ of the shore, improvements to the nitrogen retention capabilities of septic systems, and controls on fertilizer use for lawns situated near the coast. Focusing on residential lawn fertilizer applications, Law et al. (2004) 
estimated optimal application rates, finding them to depend upon the soil bulk density and nitrogen content and the market values and vintages of homes. In the Mississippi River watershed, Ribaudo et al. (2001) found that fertilizer application controls (i.e., standards) were more cost-effective than either wetland restoration or the purchase of conservation easements restricting agricultural development.

County and municipal fertilizer ordinances have been implemented increasingly in many locations along the Florida Gulf coast (Fig. 9), but the physical evidence linking K. brevis blooms and anthropogenic nutrients continues to be a subject of scientific debate. In Fig. 12, we place a question mark over the arrow leading from these policies to the bloom formation box because of the significant uncertainty surrounding their potential effectiveness in mitigating Florida red tides. Notably, results from the literature on anthropogenic nutrient releases and the costs to society emphasize the importance of local environmental conditions, thereby highlighting the need for research on site-specific nutrient flows and how they might lead to impacts from $K$. brevis blooms along the Florida Gulf coast.

\section{Policies to reduce the potential hazard}

A second point at which policies may be implemented lies between the bloom and the potentially affected population. These responses include monitoring for the presence of blooms; the development of methods to forecast the initiation, transport, duration, and fate of blooms; methods of alerting the public, either through signage posted at beaches, a beach condition reporting system, or a poison control hotline; publication of the existence of a bloom through the media (Fig. 14), or in technical or scientific publications; the conduct of scientific research on blooms and environmental correlates; and the implementation of education programs to teach the public about the nature and scope of the hazards.

Alerts comprise health advisories or HAB warning schemes such as the following examples:

- Mote Marine Laboratory in Sarasota, Florida has introduced a "Beach Conditions Report," which produces daily data on bloom status and beach conditions as well as the occurrence of respiratory symptoms on beaches in Sarasota.

- The Florida Dept of Health Aquatic Toxins Program and the Florida Poison Information Center/Miami have established an Aquatic Toxins Hotline to provide information and disease surveillance for residents, tourists, and their healthcare providers to help mitigate the effects of Florida red tide blooms.

- A non-governmental advocacy organization, Solutions to Avoid Red Tide (START), and Mote Marine Laboratory have implemented a program of beach signage, the distribution of educational materials (such as the "START Card"), and the publication of public service announcements and focused articles in the media.

- The beach conditions data has been incorporated into NOAA modeling efforts to provide forecasts of Florida red tide blooms and internet publication of forecasts in the NOAA HAB Bulletin.

\section{Cost minimization}

In order to determine the socially efficient policy response to aerosolized brevetoxins, consider the following cost-minimizing framework. First, define a set of feasible policy responses to the aerosolized brevetoxin hazard:

$$
\Gamma(P)=\left[P_{1}, P_{2}, P_{3}, \ldots, P_{j}, \ldots P_{J}\right]
$$

Here, $P_{j}$ represents one policy response out of a set of $J$ feasible responses. Policy responses can be implemented continuously over a range of levels. For example, levels might comprise the frequency of publication of beach condition reports or the number of hours per day an aquatic toxin hotline is staffed. The level of a particular policy response is zero, if it is not implemented at all. Our problem is to choose the level of response, $P_{j}$, for each $j$ in the policy set, in order to minimize the discounted combined costs of illnesses and policy responses: 


$$
\min _{P} \sum_{t}\left\{C_{t}\left(I_{t}, \Gamma_{t}(P)\right) I_{t}+\sum_{t} w_{t j}\left(P_{t j}\right)\right\}(1+r)^{-t}
$$

In this framework, $I$ represents respiratory illnesses due to aerosolized brevetoxins. ${ }^{9}$ Illnesses are costly, and, in general, the costs of illnesses (c) may be an increasing function of the number of illnesses. The costs of illness may depend also on a particular combination of policy responses, and this relationship would indicate the degree of policy effectiveness for any particular combination. Policy responses are costly too, and each response involves a cost, $w_{j}$, which may be an increasing function of the relevant policy level. Further, the number of illnesses may change in each period $t$, reflecting Florida red tide bloom conditions. The costs of illness and of implementing policy responses may change over time, reflecting medical advances, new ideas for responding to bloom events, or other shifts due to technological advances or learning. The combined costs in future time periods $t$ are discounted at rate $r$.

The simplicity of this equation belies the difficulties involved in compiling data for all of the relevant variables, including respiratory illnesses; the costs of respiratory illness; the set of policy responses and their levels; the costs of implementing policy responses at different levels; and, most importantly, the effectiveness of policy responses in reducing illnesses. The latter, in particular, would require undertaking a number of experiments with alternative levels of policy instruments in order to begin to identify the effectiveness of combinations of instruments at different levels.

Fig. 15, panels (a) and (b), represents stylized versions of the problem of choosing between two alternative policy responses, say between a beach condition report and an aquatic toxins hotline. In each panel, the net benefits of a policy response $P_{j}$ are considered as a function of their effectiveness. Below the abscissa, the net benefits of a response are negative, indicating that implementing a policy with very low effectiveness would involve net losses. For any level of effectiveness, $\alpha$, we can compare the net benefits of alternative policies. In panel (a), $\mathrm{P}_{1}$ always leads to higher net benefits than $\mathrm{P}_{2}$, and $\mathrm{P}_{1}$ is the clear choice of policy response. In panel (b), the responses differ in their net benefits for any level of effectiveness. At low levels of effectiveness, say $\alpha_{0}, \mathrm{P}_{1}$ is preferred to $\mathrm{P}_{2}$. At higher levels of effectiveness, say $\alpha_{1}$, $\mathrm{P}_{2}$ is preferred to $\mathrm{P}_{1}$. In reality, the position of either line may be uncertain, leading to significant difficulties in choosing among policies.

\section{Policies to reduce the population at risk}

The third set of policy responses involves actions taken by individuals to reduce the likelihood of impacts. These actions involve choosing to visit beaches that are not in the vicinity of a bloom; remaining indoors and using air conditioning; traveling inland away from the coast; and deciding to change the location of vacations or the place of residence for snowbirds. The remaining population is at risk of exposure to aerosolized brevetoxins and to contracting respiratory illnesses.

Table 2 presents a qualitative listing of the types of behavioral responses associated with policies that encourage reducing the population at risk. There may be non-market economic losses associated with these behaviors, including the loss of recreational benefits to vacationers and the loss of residential benefits to snowbirds. There may also be market economic losses, including lost trade to restaurants, hotels, and tourist businesses, among others. These lost benefits may be significant in specific locations (cf., Morgan et al. 2009), although consumers are able to substitute by traveling to other beaches and other vacation spots. Snowbirds may not be as mobile and, due to age, they may be more susceptible to illnesses from aerosolized brevetoxins.

\footnotetext{
${ }^{9}$ This variable also could represent other forms of adverse effects, such as economic losses felt by tourists or to the tourism industry.
} 
Table 2: Behavioral Responses to Policies and Associated Economic Effects

\begin{tabular}{|c|c|c|c|}
\hline $\begin{array}{l}\text { Behavioral Re- } \\
\text { sponse }\end{array}$ & $\begin{array}{l}\text { Types of Economic } \\
\text { Effects }\end{array}$ & $\begin{array}{l}\text { Potential Mitigating } \\
\text { Factor }\end{array}$ & Evidence \\
\hline $\begin{array}{l}\text { Reduced numbers of } \\
\text { beach visits }\end{array}$ & $\begin{array}{l}\text { Lost non-market value } \\
\text { of beach visits (con- } \\
\text { sumers surplus) }\end{array}$ & $\begin{array}{l}\text { Increased use of substi- } \\
\text { tute beaches }\end{array}$ & $\begin{array}{l}\text { Morgan et al. } \\
\text { (2010) }\end{array}$ \\
\hline $\begin{array}{l}\text { Reductions in meals } \\
\text { taken at coastal res- } \\
\text { taurants and stays at } \\
\text { coastal hotels }\end{array}$ & $\begin{array}{l}\text { Lost consumer surplus- } \\
\text { es to patrons; lost pro- } \\
\text { ducer surpluses to res- } \\
\text { taurateurs, and hoteliers }\end{array}$ & $\begin{array}{l}\text { Increased trade at in- } \\
\text { land or coastal sites } \\
\text { away from the bloom } \\
\text { location }\end{array}$ & $\begin{array}{l}\text { Morgan et al. } \\
(2008)\end{array}$ \\
\hline $\begin{array}{l}\text { Reductions in sea- } \\
\text { sonal snowbird stays } \\
\text { and vacationer visits }\end{array}$ & $\begin{array}{l}\text { Lost residential and } \\
\text { recreational surpluses } \\
\text { to snowbirds and vaca- } \\
\text { tioners; lost producer } \\
\text { surpluses to local busi- } \\
\text { nesses }\end{array}$ & $\begin{array}{l}\text { Increased tourism at } \\
\text { inland or coastal sites } \\
\text { away from the bloom } \\
\text { location; snowbird } \\
\text { population may not be } \\
\text { as mobile as vacation- } \\
\text { ers }\end{array}$ & -- \\
\hline $\begin{array}{l}\text { Increase in physician } \\
\text { visits and hospitali- } \\
\text { zations }\end{array}$ & $\begin{array}{l}\text { Costs of non-market } \\
\text { pain and suffering; } \\
\text { chronic productivity } \\
\text { losses }\end{array}$ & $\begin{array}{l}\text { Medical treatment may } \\
\text { prevent the costs of } \\
\text { more serious complica- } \\
\text { tions }\end{array}$ & $\begin{array}{l}\text { Kirkpatrick et al. } \\
2006 \\
\text { Hoagland et al. } \\
2009\end{array}$ \\
\hline $\begin{array}{l}\text { Reductions in appli- } \\
\text { cations of lawn ferti- } \\
\text { lizer }\end{array}$ & $\begin{array}{l}\text { Reductions in property } \\
\text { values due to less at- } \\
\text { tractive lawns }\end{array}$ & $\begin{array}{l}\text { Benefits to homeown- } \\
\text { ers of increased leisure } \\
\text { time }\end{array}$ & -- \\
\hline
\end{tabular}

\section{Policies to mitigate illnesses}

Once individuals in the population have been exposed to aerosolized brevetoxins or to NSP, economic damages will result as the consequence of the costs of illness. Elsewhere, we have estimated these costs for emergency room visits resulting from respiratory illnesses (Hoagland et al. 2009). Note that personal or medical actions can be taken to mitigate the severity of the illnesses. Depending upon the severity level, these actions may range from self-medication through the purchase of over-the-counter pharmaceuticals to physician visits to emergency department visits or longer hospitalizations. Further work is needed to characterize the extent to which medical treatments mitigate the potential costs of more serious or chronic illnesses.

\section{Discussion}

We began this chapter with a question about whether humans face the right sorts of incentives to respond to Florida red tide in ways that minimize the combined costs of impacts and responses. A deeper understanding of the coupled aspects of this nature-human system could provide insights into possible answers, providing a useful framework for conceptualizing the nature of the hazard. For example, knowledge of system heterogeneities can us help focus on areas off the southwest coast of Florida, where human populations are large and growing at rapid rates and where there is growing, yet still arguably circumstantial, evidence of anthropogenic contributions to macro-nutrient supplies that could support frequent, large, and persistent Florida red tide blooms. This evidence suggests that an ecological threshold may have been crossed, leading to a legacy comprising a stock (pool) of nutrients, heretofore lacking, that is capable of supplying the requirements for blooms to form, grow, and endure on a regular basis. 
Time lags between human activities, the occurrence of blooms, and human responses render problematic a clear understanding of potential management approaches, and reciprocal feedbacks sometimes lead to surprises. Surprises include variable bloom toxicities and the seemingly random occurrence of blooms, provoking multiple competing scientific hypotheses about why Florida red tides occur (Vargo 2009), and rendering predictions difficult (Stumpf et al. 2009) and the assessment of policy effectiveness problematic. Even with all of these complexities, the human populations of the Florida Gulf coast appear so far to be resilient to Florida red tides, affected more by the hazards of coastal storms and fluctuations in general economic conditions (recessions) affecting the major industry, coastal tourism. Public health and economic impacts can be identified and measured, but so far they have been relatively small and fleeting. Programs of shellfish management, beach alerts, scientific research, and public education have been in place for at least a decade, helping to mitigate the more obvious effects on human health and welfare. While these programs are not and may never be fully effective, and public awareness of the hazard may fall far short of complete (Larkin and Adams 2008), they clearly represent actions motivated toward reducing vulnerability.

The reasons for resilience in the face of the Florida red tide hazard may lie in the abilities of humans to adapt by learning and through the selection of policies that, while not fully efficient, are at least boundedly rational. County and municipal fertilizer ordinances may help to control the flux of anthropogenic nutrients into coastal environments, thereby reducing the potential for eutrophication. Certainly other water pollution control policies, such as wastewater treatments, stormwater runoff retention ponds, and agricultural conservation practices, among others, work in the same way on larger scales. While Florida red tide bloom toxicity may be exacerbated in nutrient-poor environments, other bloom dimensions, including spatial extent, cell density, and duration may be simultaneously constrained. Further efforts to increase our scientific understanding of the reasons for Florida red tides remain an important mode of policy response, helping to sharpen the focus on future actions to mitigate the hazard. Indeed, strong arguments should be made for a multi-disciplinary natural and social scientific approach, in line with the coupled nature-human dimensions of the problem, to enhance the likelihood that an evolving scientific understanding can be assimilated and acted upon more effectively (Backer 2009).

The human responses to significant Florida red tide blooms are episodic, tracking bloom occurrence closely. Fig 16 presents four indexes depicting blooms of Florida red tide in the Pinellas to Lee county region, red tide media coverage in the Sarasota Herald Tribune, marine scientific funding for research on $K$. brevis, and the enactment of county and municipal fertilizer ordinances. These indexes show how media reports closely follow the occurrence of the blooms, followed with a minimal lag by marine scientific research. The enactment of the fertilizer ordinances follow with an even longer lag. The length of the series is short, making it difficult to see clearly whether the conduct of science and the enactment of pollution controls are helping to mitigate the hazard. As is characteristic of human responses to other hazards, however, both the public's attention, as reflected in media coverage, and the impetus for science funding appear to wax and wane in step with the hazard. It remains to be seen whether the absence of a steadier effort, meaning that society repeatedly loses its focus on the problem, would lead eventually to a longerterm vulnerability of humans to Florida red tides. While it is certain that human populations will continue to move into harm's way, by locating and vacationing along the Florida Gulf coast, unless effective policy responses based upon sound science can be identified, agreed upon, and implemented, it seems certain also that the hazard itself will continue to grow. 


\section{References Cited}

Adams, C., S. Larkin, D. Mulkey, A. Hodges and A. Ballayram. 2002. Measuring the economic consequences and public awareness of red tide events in Florida. St. Petersburg, FL: Harmful Algal Task Force, Florida Marine Research Institute, pp. 1-145.

Adger, W.N., T.P. Hughes, C. Folke, S.R. Carpenter and J. Rockstrom. 2005. Social-ecological resilience to coastal disasters. Sci. 309: 1036-1039.

Anderson, D.M., P.M. Glibert and J.M. Burkholder. 2002. Harmful algal blooms and eutrophication: nutrient sources, composition and consequences. Est. 25: 562-584.

Anderson, Z. 2013. Lingering red tide hangs over tourism season. Sara. Herald Trib. (January 4): A01.

Backer, L.C. 2009. Impacts of Florida red tides on coastal communities. Harm. Alg. 8: 618-622.

Berg, G.M., M. Balode, I. Purina, S. Bekere, C. Bechemin and S.Y. Maestrini. 2003. Plankton community composition in relation to availability and uptake of oxidized and reduced nitrogen. Aquat. Microb. Ecol. 30: 263-274.

Bossart, G., D. Baden, R. Ewing, B. Roberts, and S. Wright. 1998. Brevetoxicosis in manatees (Trichechusmanatus latirostris) from the 1996 epizootic; gross, histologic and immunohistochemical features. Toxicol. Pathol. 26: 276-282.

Brand, L.E. and A. Compton. 2007. Long-term increase in Karenia brevis abundance along the southwest Florida coast. Harm. Alg. 6: 232-252.

Bryant, J., F. Chapin III and D. Klein. 1983. Carbon/nutrient balance of boreal plants in relation to vertebrate herbivory. Oikos 40: 357-368.

Charette,M.A., P.B. Henderson, C.F. Breier and Q. Liu. 2013. Submarine groundwater discharge in a river-dominated Florida estuary. Mar. Chem. http://dx.doi.org/10.1016/j.marchem.2013.04.001.

Faris, J., A. Beet, R. Lazensky and A. Reich. 2013. The incidence of neurotoxic shellfish poisonings during Florida red tide (Karenia brevis) blooms: is shellfish management effective at mitigating outbreaks? Mimeo. Tallahasee: Florida Department of Health.

Feng, H., M. Jha and P. Gassman. 2009. The allocation of nutrient load reduction across a watershed: assessing delivery coefficients as an implementation tool. Rev. Ag. Econ. 31: 183-204.

Fleming, L.E., B. Kirkpatrick, L.C. Backer, C.J. Walsh, K. Nierenberg, J. Clark, A. Reich, J. Hollenbeck, Janet Benson, Y. S. Cheng, J. Naar, R. Pierce, A.J. Bourdelais, W.M. Abraham, G. Kirkpatrick, J. Zaias, A. Wanner, E. Mendes, S. Shalat, P. Hoagland, W. Stephan, J. Bean, S. Watkins, T. Clarke, M. Byrne and D.G. Baden. 2011. Review of Florida red tide and human health effects. Harm. Alg. 10: 224-233.

Fleming, L.E., J.A. Bean, B. Kirkpatrick, Y.S. Chung, R. Pierce, J. Naar, K. Nierenberg, L.C. Backer, A. Wanner, A. Reich, Y. Zhou, S. Watkins, M. Henry, J. Zaias, W.M. Abraham, J. Benson, A. Cassedy, J. Hollenbeck, G. Kirkpatrick, T. Clarke and D.G. Baden. 2009. Exposure and effect assessment of aerosolized red tide toxins (brevetoxins) and asthma. Environ. Health Persp. 117: 1095-1100.

Flewelling, L.J., J.P. Naar, J.P. Abbott, D.G. Baden, N.B. Barros, G.D. Bossart, M-Y.D. Bottein, D.G. Hammond, E.M. Haubold, C.A. Heil, M.S. Henry, H.M. Jacocks, T.A. Leighfield, R.H. Pierce, T.D. Pitchford, S.A. Rommel, P.S. Scott, K.A. Steidinger, E.W. Truby, F.M. Van Dolah and J.H. Landsberg. 2005. Red tides and marine mammal mortalities: unexpected brevetoxin vectors may account for deaths long after or remote from an algal bloom. Nat. 435: 755-756. 
Habas, E.J. and C. Gilbert. 1975. A preliminary investigation of the economic effects of the HAB of 1973-1974 on the west coast of Florida. pp. 499-505. In V.R. LoCicero [ed.]. Proceedings of the First International Conference on Toxic Dinoflagellate Blooms. The Massachusetts Science and Technology Foundation, Boston, Massachusetts.

Hardison D.R., W.G. Sunda, D. Shea and R.W. Litaker. 2013. Increased toxicity of Karenia brevis during phosphate limited growth: ecological and evolutionary implications. PLoS ONE 8: e58545. doi:10.1371/journal.pone.0058545.

Hardison DR, W.G. Sunda, R.W. Litaker, D. Shea and P.A. Tester. 2012. Nitrogen limitation increases brevetoxins in Karenia brevis (Dinophyceae): Implications for bloom toxicity. J. Phycol. 48: 844858.

Hoagland, P., D. Jin, A. Beet, A. Reich, B. Kirkpatrick, S. Ullmann, S. Watkins, L.E Fleming. 2013. Linking Forida red tides to human health effects: data issues and preliminary signals. Mimeo. Marine Policy Center Woods Hole Oceanographic Institution, Woods Hole, Massachusetts, USA.

Hoagland, P., D. Jin, L.Y. Polansky, B. Kirkpatrick, G. Kirkpatrick, L.E. Fleming, A. Reich, S.M. Watkins, S.G. Ullmann and L.C. Backer. 2009. The costs of respiratory illnesses arising from Florida Gulf Coast Karenia brevis blooms. Environ. Health Persp. 117:1239-1243.

Hu, C.M., F.E. Muller-Karger and P.W. Swarzenski. 2006. Hurricanes, submarine groundwater discharge, and Florida's red tides. Geophys. Res. Lett. 33: 11.

Kirkpatrick, B., J.A. Bean, L.E. Fleming, G. Kirkpatrick, L. Grief, K. Nierenberg, A. Reich, S. Watkins and J. Naar. 2010. Gastrointestinal emergency room admissions and Florida red tide blooms. Harm. Alg. 9: 82-86.

Kirkpatrick, B., L.E. Fleming, L.C. Backer, J.A. Bean, R. Tamer, G. Kirkpatrick, T. Kane, A. Wanner, D. Dalpra, A. Reich and D.G. Baden. 2006. Environmental exposures to Florida red tides: effects on emergency room respiratory diagnoses admissions. Harm. Alg. 5: 526-533.

Kirkpatrick, B., L.E. Fleming, D. Squicciarini, L.C. Backer, R. Clark, W. Abraham, J. Benson, Y.S. Cheng, D. Johnson, R. Pierce, J. Zaias, G. Bossart and D.G. Baden. 2004. Literature review of Florida red tide: implications for human health. Harm. Alg. 3: 99-115.

Kusek, K.M., G. Vargo and K. Steidinger. 1999. Gymnodinium breve in the field, in the lab, and in the newspaper-a scientific and journalistic analysis of Florida red tides. Contrib. Mar. Sci. 34: 1229.

Laist, D.W. and J.E. Reynolds. 2005a. Influence of power plants and other warm-water refuges on Florida manatees. Mar. Mam. Sci. 21: 739-764.

Laist, D.W. and J.E. Reynolds. 2005b. Florida manatees, warm-water refuges, and an uncertain future. Coast. Manag. 33: 279-295.

Laist D.W., C. Taylor and J.E. Reynolds. 2013. Winter habitat preferences for Florida manatees and vulnerability to cold. PLoS ONE 8: e58978.

Larkin, S.L. and C.M. Adams. 2007. Red tides and coastal businesses: measuring economic consequences in Florida. Soc. Nat. Res. 20: 849-859.

Larkin, S.L. and C.M. Adams. 2008. Public awareness and knowledge of red tide blooms. J. Extens. 46: art. no. 2COM2.

Law, N., L. Band and M. Grove. 2004. Nitrogen input from residential lawn care practices in suburban watersheds in Baltimore County, MD. J. Environ. Plan. Manag. 47: 737-755. 
Layzer, J.A. 2008. Natural Experiments: Ecosystem-Based Management and the Environment. MIT Press Cambridge, Massachusetts, USA.

Liu, J., T. Dietz, S.R. Carpenter, C. Folke, M. Alberti, C.L. Redman, S.H. Schneider, E. Ostrom, A.N. Pell, J. Lubchenco, W.W. Taylor, Z. Ouyang, P. Deadman, T. Kratz and W. Provencher. 2007a. Coupled human and natural systems. Ambio 36: 639-649.

Liu, J., T. Dietz, S.R. Carpenter, M. Alberti, C. Folke, E. Moran, A.N. Pell, P. Deadman, T. Kratz, J. Lubchenco, E. Ostrom, Z. Ouyang, W. Provencher, C.L. Redman, S.H. Schneider and W.W. Taylor. 2007b. Complexity of coupled human and natural systems. Sci. 317: 1513-1516.

Magaña, H.A., C. Contreras and T.A. Villareal. 2003. A historical assessment of Karenia brevis in the western Gulf of Mexico. Harm. Alg. 2: 163-171.

Mendoza, W.G., R.N. Mead, L.E. Brand, D. Shea. Determination of brevetoxin in recent marine sediments. Chemos. 73: 1373-1377.

Morgan, K.L., S.L. Larkin and C.M. Adams. 2009. Empirical analysis of media versus environmental impacts on park attendance. Tour. Manag. doi:10.1016/ j.tourman.2010.07.010.

Morgan, K.L., S.L. Larkin and C.M. Adams. 2010. Firm-level economic effects of HABS: a tool for business loss assessment. Harm. Alg. 8: 212-218.

Ribaudo, M.O., R. Heimlich, R. Claassen and M. Peters. 2001. Least-cost management of nonpoint source pollution: source reduction versus interception strategies for controlling nitrogen loss in the Mississippi Basin. Ecol. Econ. 37:183-197.

Roberts, D.C., C.D. Clark, W.M. Park and B.C. English. 2008. A spatial assessment of possible water quality trading markets in Tennessee. Rev. Ag. Econ. 30: 711-728.

Rounsefell, G.A. and J.E.Evans. 1958. Large-scale experimental tests of copper sulfate as a control for the Florida red tides. Spcl. Sci. Rep. Fish. No. 270. Washington, U.S. Department of the Interior, Fish and Wildlife Service.

Russell, C.S. 1970. Losses from natural hazards. Land Econ. 46: 383-393.

Schaeffer, B.A., D. Kamykowski, L. McKay, G. Sinclair and E. Milligan. 2009. Lipid class, carotenoid, and toxin dynamics of Karenia brevis (Dinophyceae) during diel vertical migration. J. Phycol. 45: 154-163.

Scheller, K., B. Kirkpatrick, K. Nierenberg, M. Byrne, L.E. Fleming, L. Bennett, A. Reich, G. Hitchcock, G. Kirkpatrick, S. Ullman and P. Hoagland. 2013. Fertilizer ordinances and Florida red tide: community responses to harmful algal blooms. Mimeo. Mote Marine Laboratory, Sarasota, Florida, USA.

Sengco, M. 2009. Prevention and control of Karenia brevis blooms. Harm. Alg. 8: 623-628.

Smith, C.G. and P.W. Swarzenski. 2012. An investigation of submarine groundwater-borne nutrient fluxes to the west Florida shelf and recurrent harmful algal blooms. Limnol. Oceanog. 57: 471485.

Smith, S.K. and M. House. 2006. Snowbirds, sunbirds, and stayers: seasonal migration of elderly adults in Florida. J. Gerontol. 61B: S232-S239.

Smith Travel Research, Inc. (STR). 2012. Customized data on Florida county hotel and motel occupancy and rental rates. SHARE Center, STR, Hendersonville, Tennessee, USA.

Steidinger, K.A., G.A. Vargo, P.A. Tester and C.R. Tomas. Bloom dynamics and physiology of Gymnodinium breve with emphasis on the Gulf of Mexico. pp. 133-153. In: D.M. Anderson, A.D. 
Cembella and G.M. Hallegraeff [eds.] 1998. Physiological Ecology of Harmful Algal Blooms. Springer Verlag, Berlin, Germany.

Strobl, E. 2011. The economic growth impact of hurricanes: evidence from US coastal counties. Rev. Econ. Stat. 93: 575-589.

Stumpf, R.P., M.C. Tomlinson, J.A. Calkins, B. Kirkpatrick, K. Fisher, K. Nierenberg, R. Currier and T.T. Wynne. 2009. Skill assessment for an operational algal bloom forecast system. J. Mar. Sys. 76: 151-161.

Swarzenski, P.W., C. Reich, K.D. Kroeger and M. Baskaran. 2007. Ra and Rn isotopes as natural tracers of submarine groundwater discharge in Tampa Bay, Florida. Mar. Chem. 104: 69-84.

Tomlinson, M.C., T.T. Wynne and R.P. Stumpf. 2009. An evaluation of remote sensing techniques for enhanced detection of the toxic dinoflagellate, Karenia brevis. Rem. Sens. Environ. 113: 598-609.

Turner, B.L, R.E. Kasperson, P.A. Matson, J.J. McCarthy, R.W. Corell, L. Christensen, M. Eckley, J.X. Kasperson, A. Luers, M.L. Martello, C. Polsky, A. Pulsipher and A. Schiller. 2003. A framework for vulnerability analysis in sustainability science. PNAS 100: 8074-8079.

Valiela, I., G. Collins, J. Kremer, K. Lajtha, M. Geist, B. Seely, J. Brawley, C.H. Sham. 1997. Nitrogen loading from coastal watersheds to receiving estuaries: new method and application. Ecological Applications 7(2):358-380.

Vargo, G.A. 2009. A brief summary of the physiology and ecology of Karenia brevis Davis (G. Hansen and Moestrup comb. nov.) red tides on the West Florida Shelf and of hypotheses posed for their initiation, growth, maintenance, and termination. Harm Alg. 8: 573-584.

Vargo, G.A., K.L. Carder, W. Gregg, E. Shanley and C. Heil. 1987. The potential contribution of primary production by red tides to the west Florida shelf ecosystem. Limnol. Oceanog. 32: 762-767.

Walker, B. and A.J. Myers. 2004. Thresholds in ecological and socio-ecological systems: a developing database. Ecol. Soc. 9(2): art. 3 [online].

Widmer, R.J. 1988. The Evolution of the Calusa. The University of Alabama Press, Tuscaloosa, Alabama, USA.

Zeckhauser, R. 1996. The economics of catastrophes. J. Risk Uncert. 12:113-140. 


\section{Figure Captions}

Fig 1: The Florida Gulf coast, location of the main occurrences of Florida red tides (Tomlinson et al. 2009).

Fig. 2: Estimate of funding for monitoring and research of Florida red tides (P.H., unpublished data).

Fig. 3: Florida Gulf coast county population dynamics (US Census Bureau, various years).

Fig. 4: Estimate of visitor surge in Sarasota County, Florida. The top line is the sum of residents, snow birds, and tourists. The resident estimate is the 2005 population estimate from the US Census Bureau. The snow/sun bird estimate is the author's calculation based upon estimates found in Smith and House (2006). The tourist estimate is the author's own calculation based upon hotel/motel occupancy data from SHARE (2012). In practice, snow/sun birds also may be residents or longer term hotel/motel tourists.

Fig. 5: Panel (a): comparison of population per $\mathrm{mi}^{2}\left(2.59 \mathrm{~km}^{2}\right)$ for the 23 Florida Gulf coast counties in 1930 (black bars) and 2010 (gray bars). This panel shows the relatively large increase along the southwest coast of Florida. Panel (b): US Census Bureau data on population per mi ${ }^{2}\left(2.59 \mathrm{~km}^{2}\right)$ in census tracts for Florida (last accessed on July 24, 2013 at: http://en.wikipedia.org/wiki/ File:Florida_population_map.png.)

Fig. 6: Map showing the distribution of the resident population by county along the Florida gulf coast and the total number of days of shellfish closures for two-digit shellfish harvest areas (SHAs). The inset depicts the days closed per year for each SHA. Author's own calculation using data compiled from Florida Department of Agriculture and Consumer Services memoranda describing closures and openings of SHAs.

Fig. 7: Indexes of current resident coastal populations and shellfish harvest area (SHA) closures associated with each of 23 Florida Gulf coast counties. The abscissa comprises proportions of the beach lengths in each county to the total length of beach $(704 \mathrm{~km})$ along the Florida Gulf coast. Beach lengths for each county can be estimated by subtracting the number associated with the first county to the right and multiplying by 704 . For example, the length of the beaches of Bay County is: $(32-22) * 704=70.4 \mathrm{~km}$.

Fig. 8: Estimate of the total number of days shellfish harvest areas (SHAs) were closed each year summed across the SHAs in Pinellas, Hillsborough, Manatee, Sarasota, Charlotte, and Lee counties. Author's own calculation using data compiled from Florida Department of Agriculture and Consumer Services memoranda describing closures and openings of SHAs.

Fig. 9: Estimate of the number of county and municipal enactments of fertilizer ordinances along the Florida Gulf coast (P.H., unpublished data).

Fig. 10: Diagram depicting the coupled nature-human system comprising Florida red tides and the human population along the Florida Gulf coast.

Fig. 11: Estimate of the percentage occupancy of hotels and motels in Sarasota county based upon SHARE data (dots). The solid line is the prediction from a model testing for the significance of the occurrence of red tide as a predictor of the occupancy rate. The measure of red tide is the annual number of months of red tide in Sarasota County, as observed in water monitoring data compiled by the Florida Fish and Wildlife Research Institute (FWRI). The model shows that measures of the supply of hotel/motel rooms (negative) and real gross domestic product (positive) are significant predictors of occupancy but the measure of red tide is not. Gray bars indicate periods of economic recession. Cross-hatched bars indicate periods of significant red tide (more than six months per year). The 2004 outlier is associated with hurricanes Charley and Jeanne, which led to a short-term increase in hotel/motel ales for people avoiding the storms and for repair crews. 
Fig. 12: The Florida red tide hazard and points and types of human responses.

Fig. 13: The marginal benefits (MB) and marginal costs (MC) of a policy response to a natural hazard.

Fig. 14: The number of articles each year mentioning red tide in the Sarasota Herald Tribune (P.H., unpublished data).

Fig. 15: Theoretical outcomes from an assessment of the net benefits of alternative policy responses, $P_{j}$, as a function of policy effectiveness, $\alpha$. Panel (a): $\mathrm{P}_{1}$ dominates $\mathrm{P}_{2}$ for all levels of effectiveness. Panel (b) $\mathrm{P}_{1}$ dominates $\mathrm{P}_{2}$ at $\alpha_{0} ; \mathrm{P}_{2}$ dominates $\mathrm{P}_{1}$ at $\alpha_{1}$.

Fig. 16: Indices of measures of Florida red tide (triangles) as measures by the total numbers of days shellfish harvest areas were closed in the counties from Pinellas to Lee; the number of articles mentioning Florida red tide in the Sarasota Herald Tribune (gray lines, diamonds); funding for science and monitoring of Florida red tide (open circles); and the enactment of county and municipal fertilizer ordinances (closed circles). To create each index, each data point is transformed to a percent of the maximum value for the relevant series. 
Fig. 1:

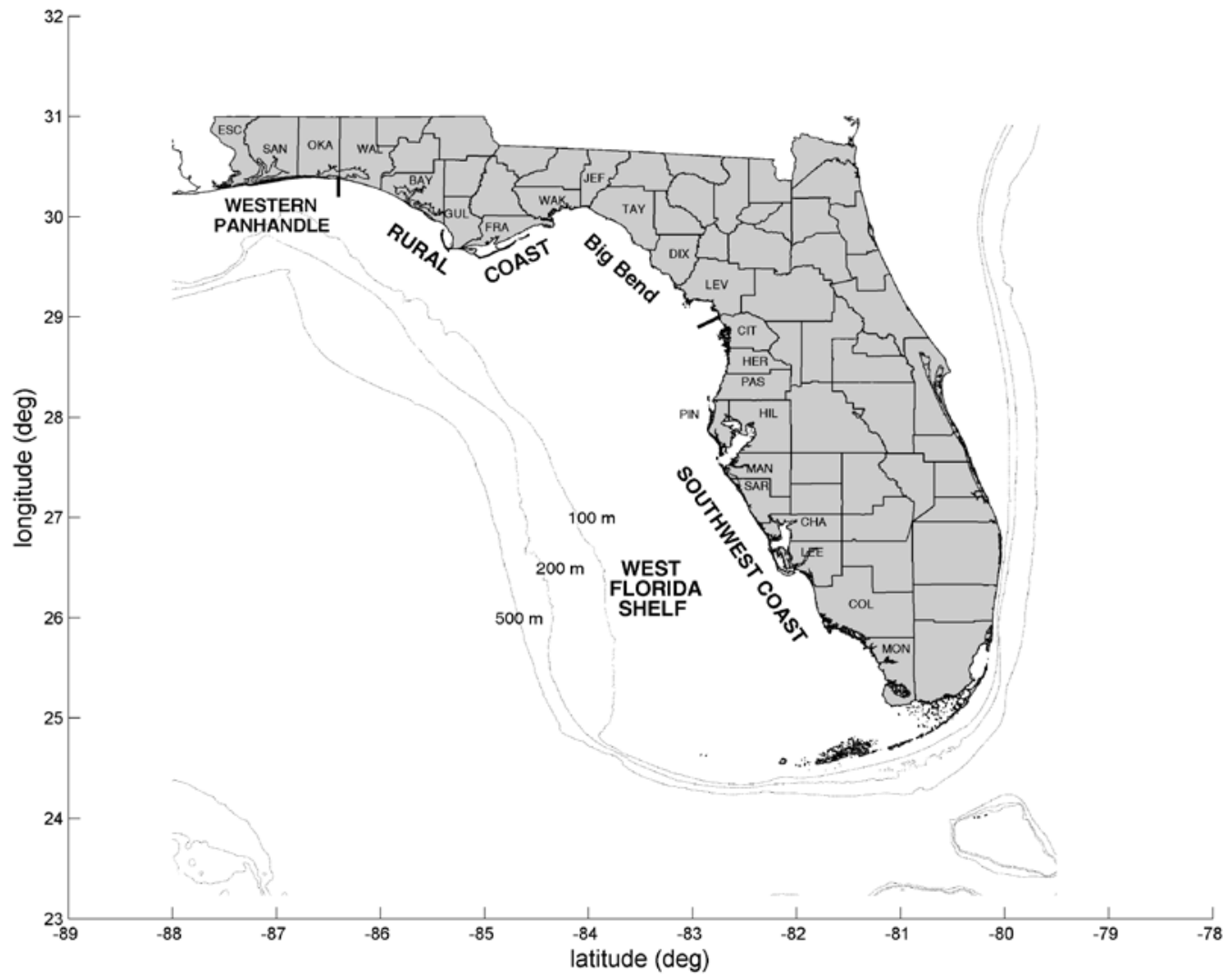


Fig. 2:

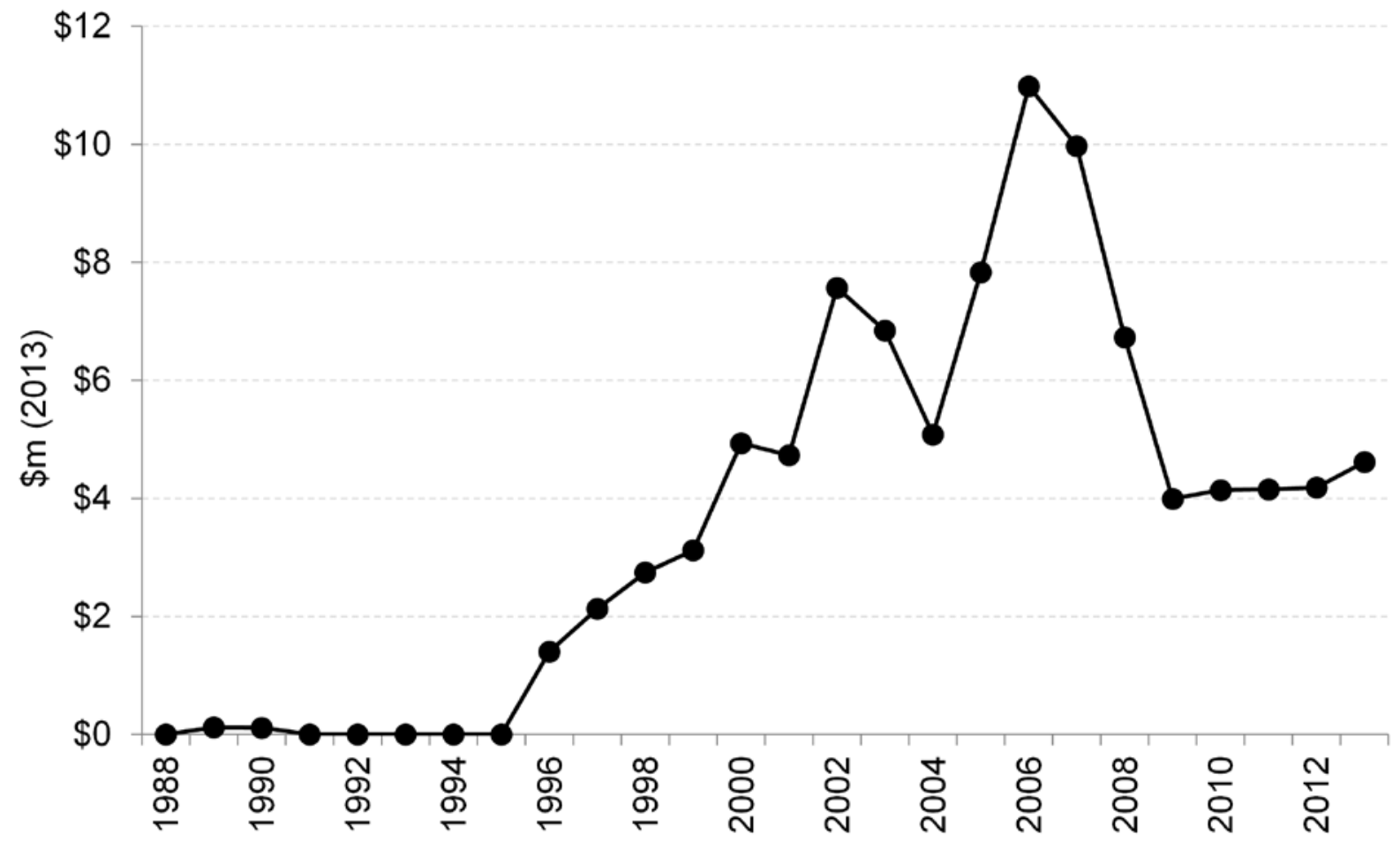


Fig. 3:

Western Panhandle Population Growth

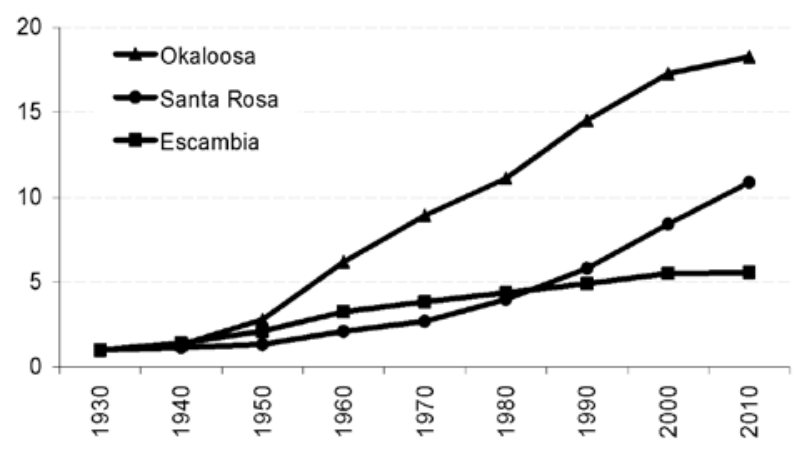

Southwest Coast Population Growth

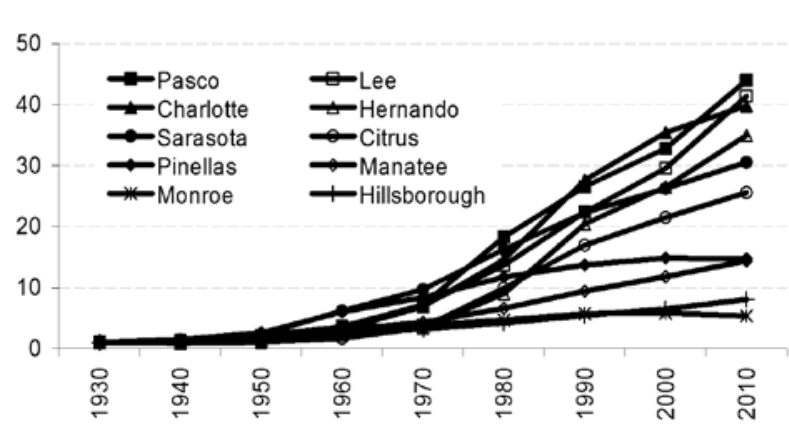

Rural Coast Population Growth

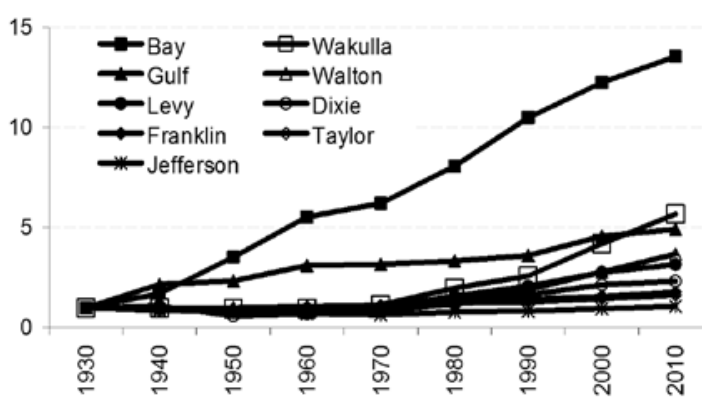

Collier County Population Growth

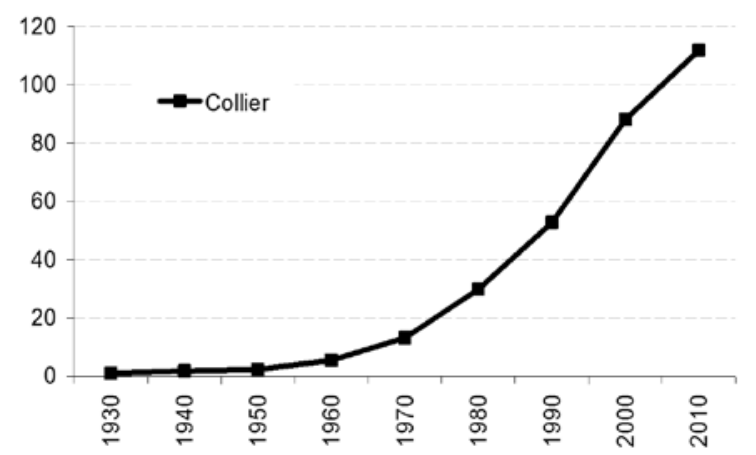


Fig. 4:

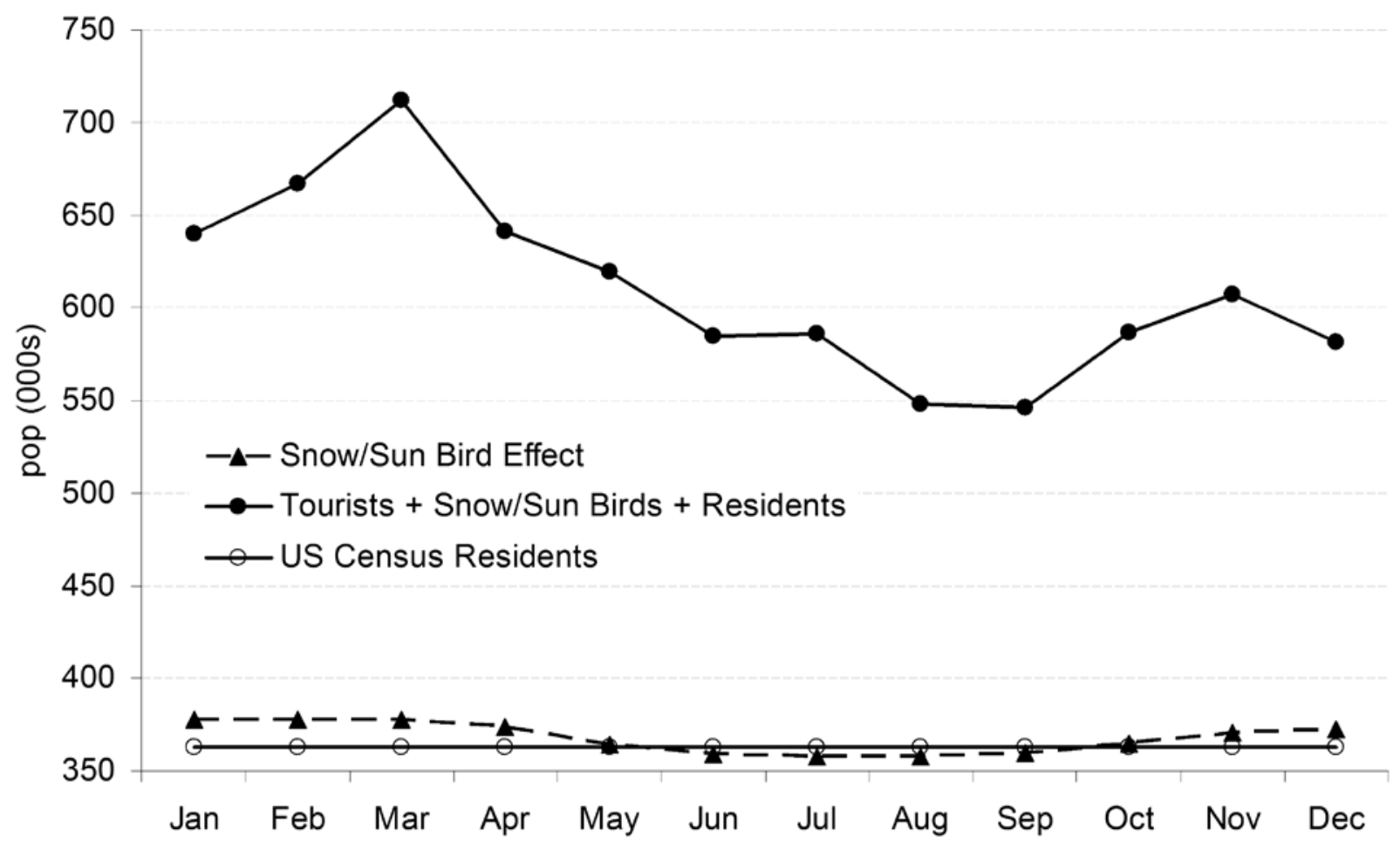


Fig 5:

(a)

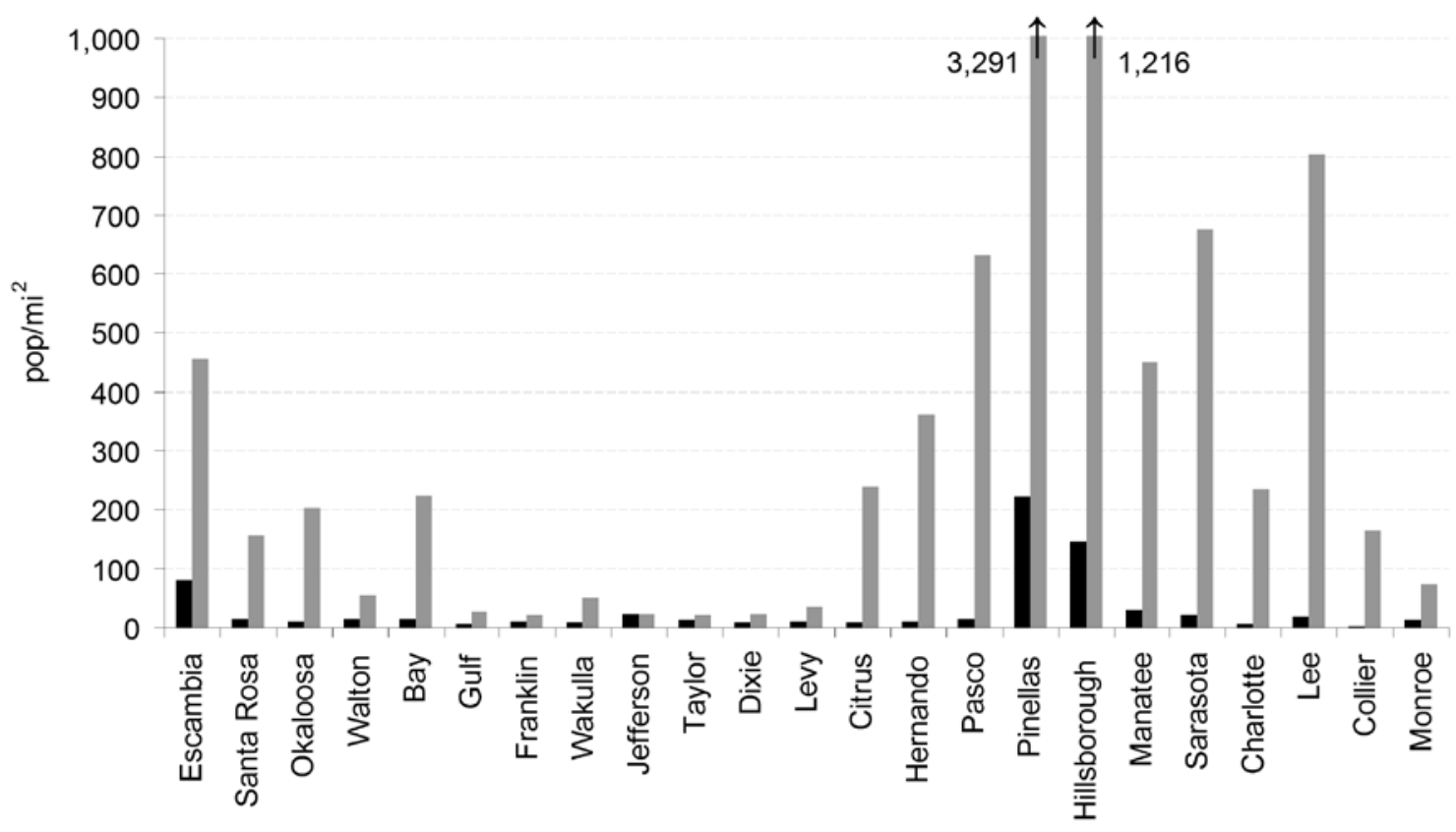

(b)

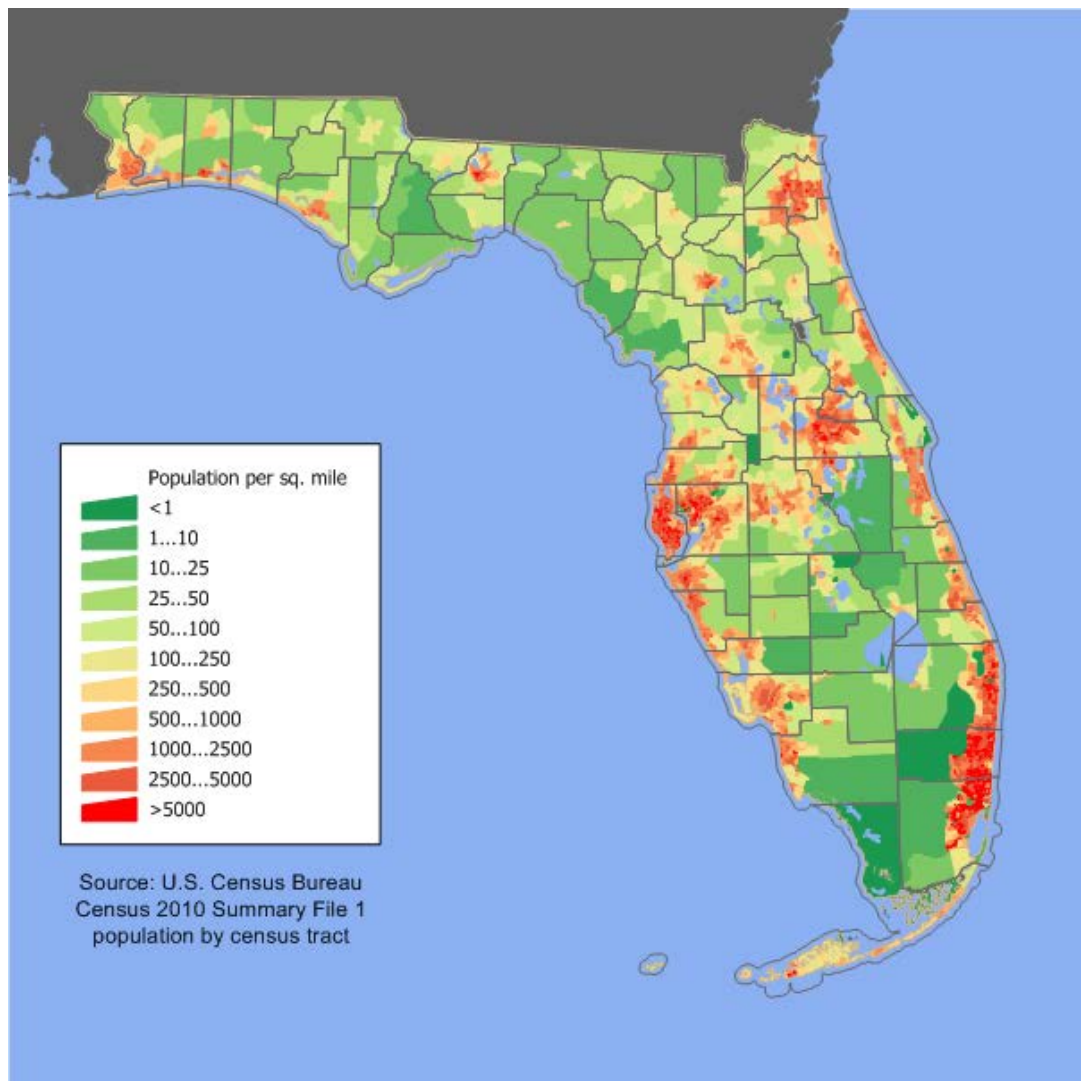


Fig. 6:

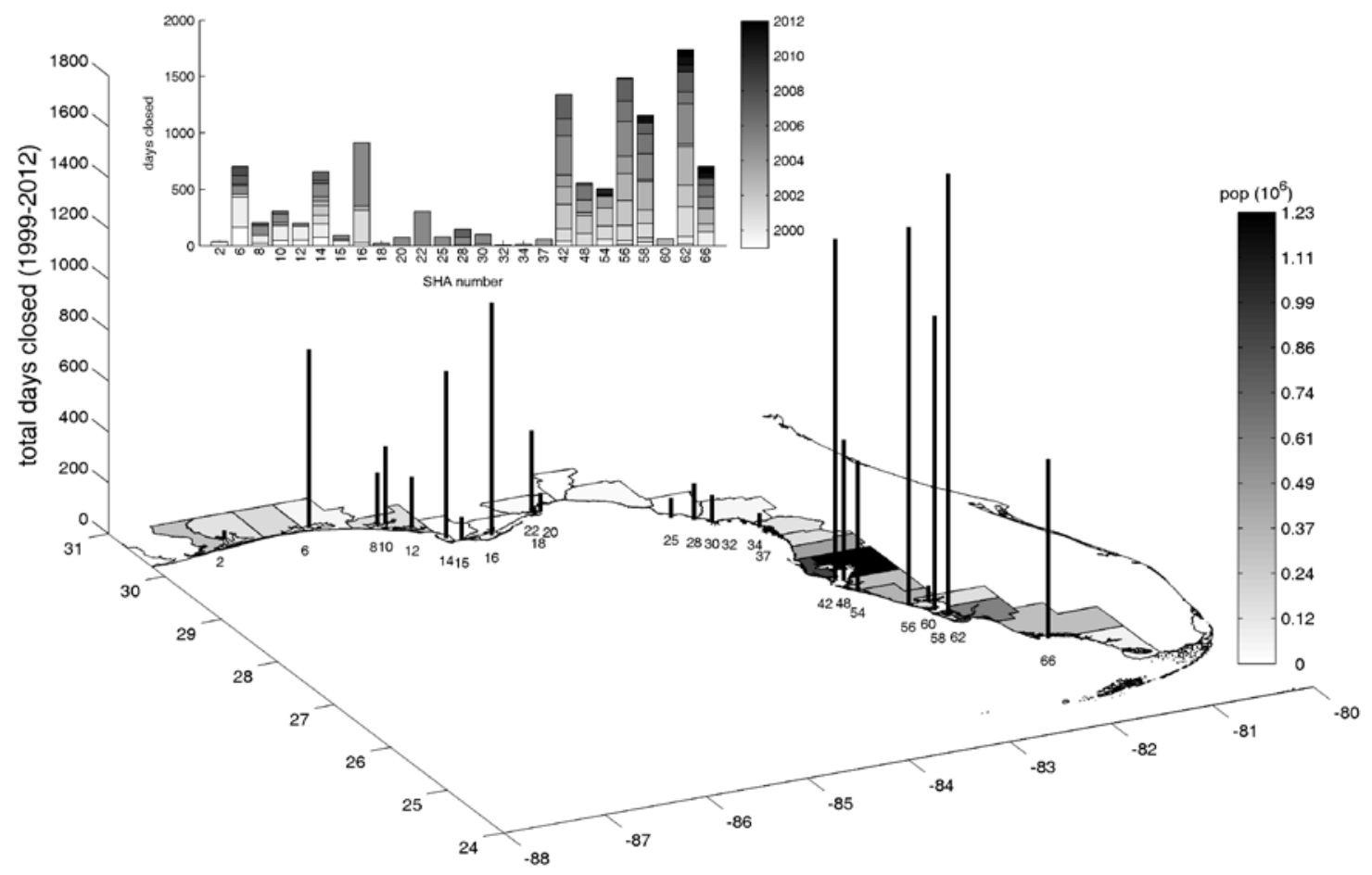


Fig. 7:

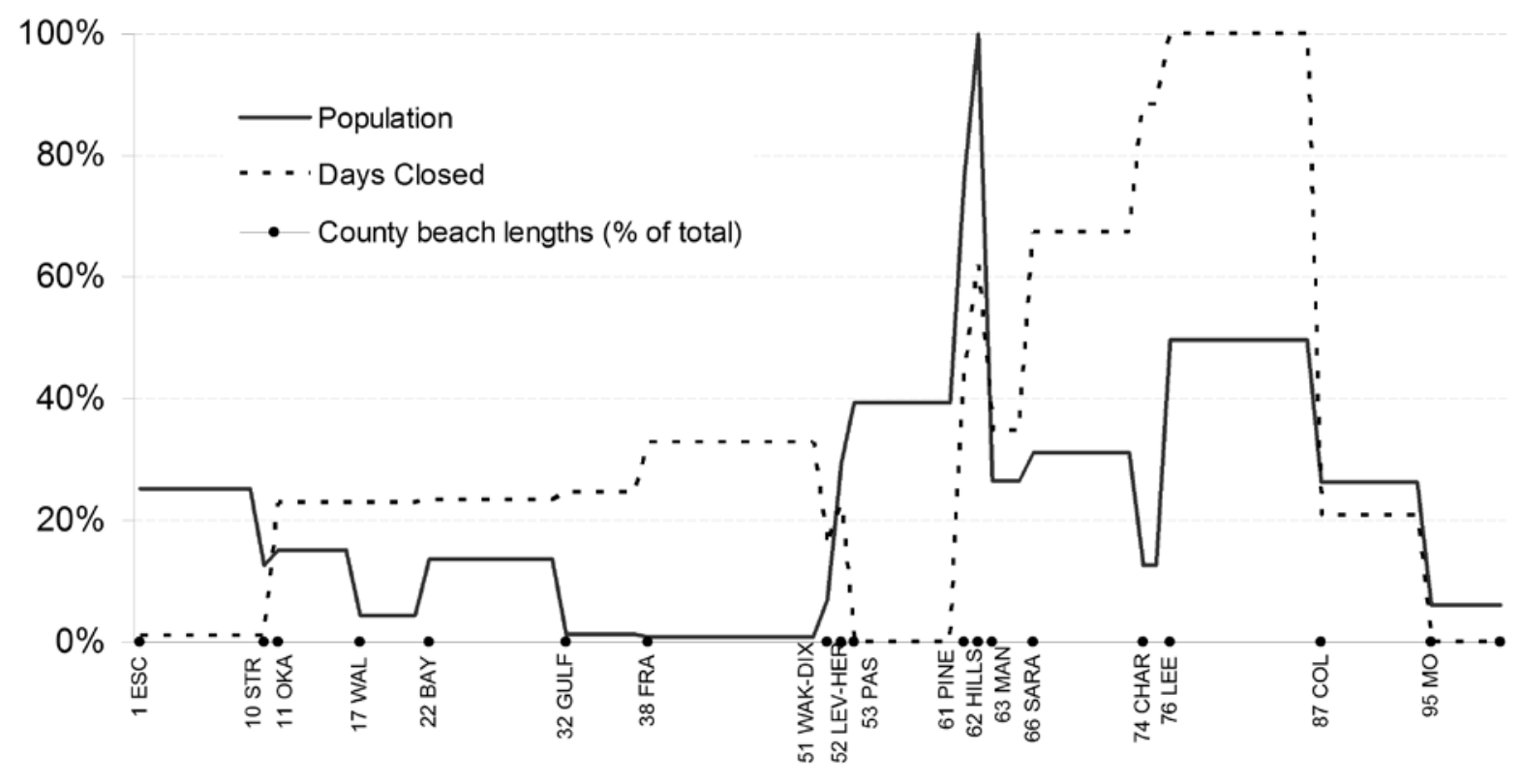


Fig. 8:

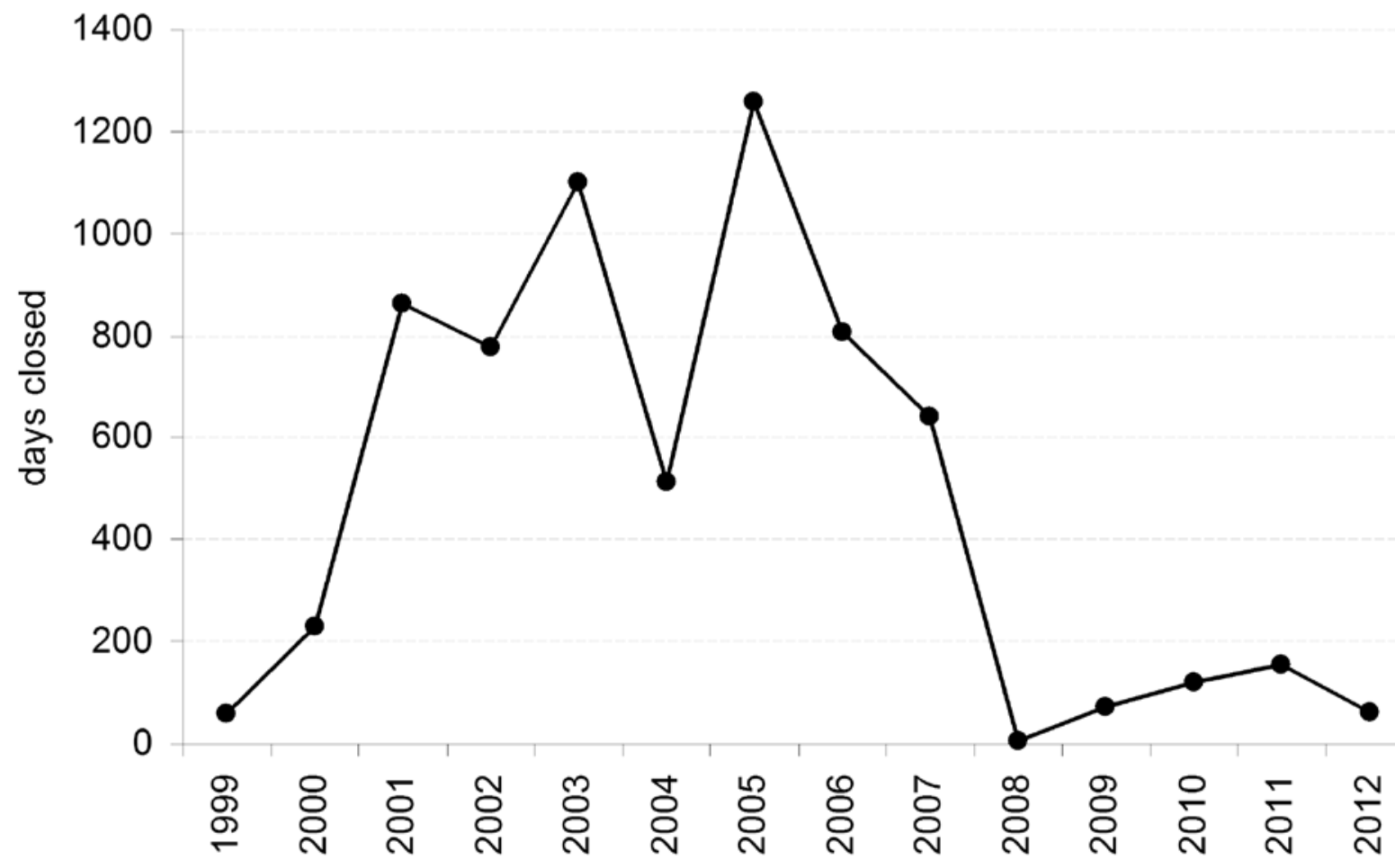


Fig. 9:

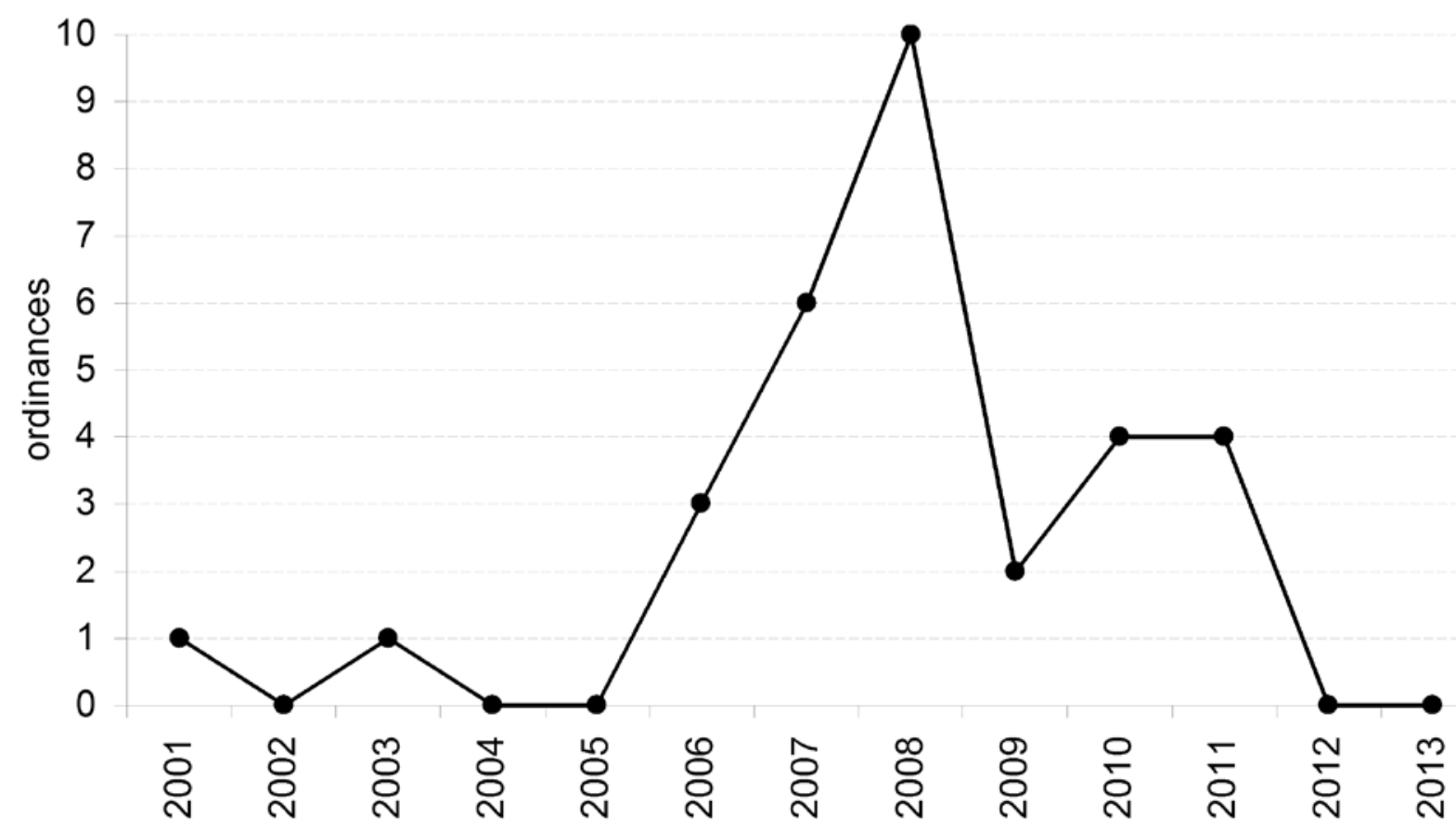


Fig. 10:

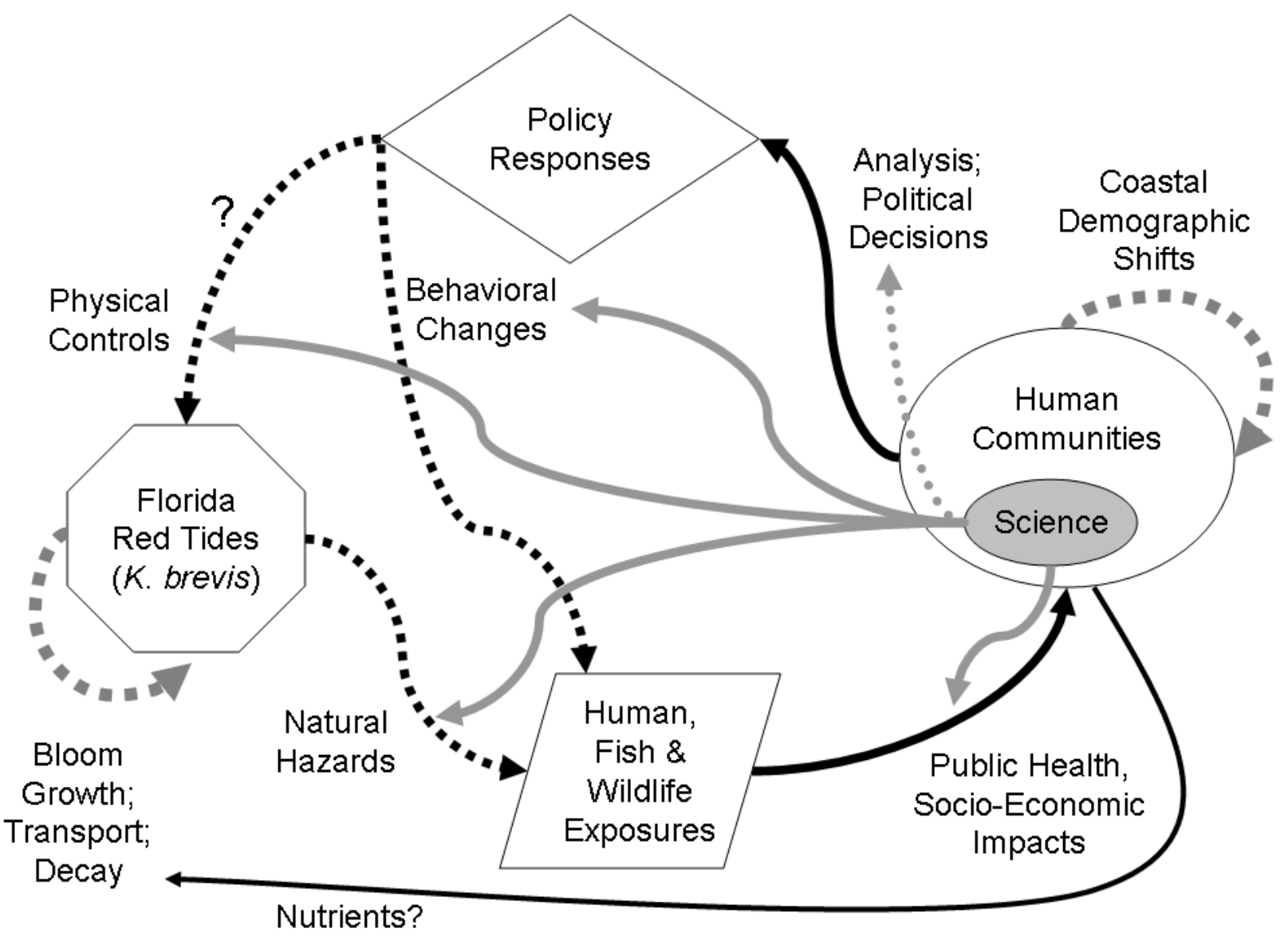


Fig. 11:

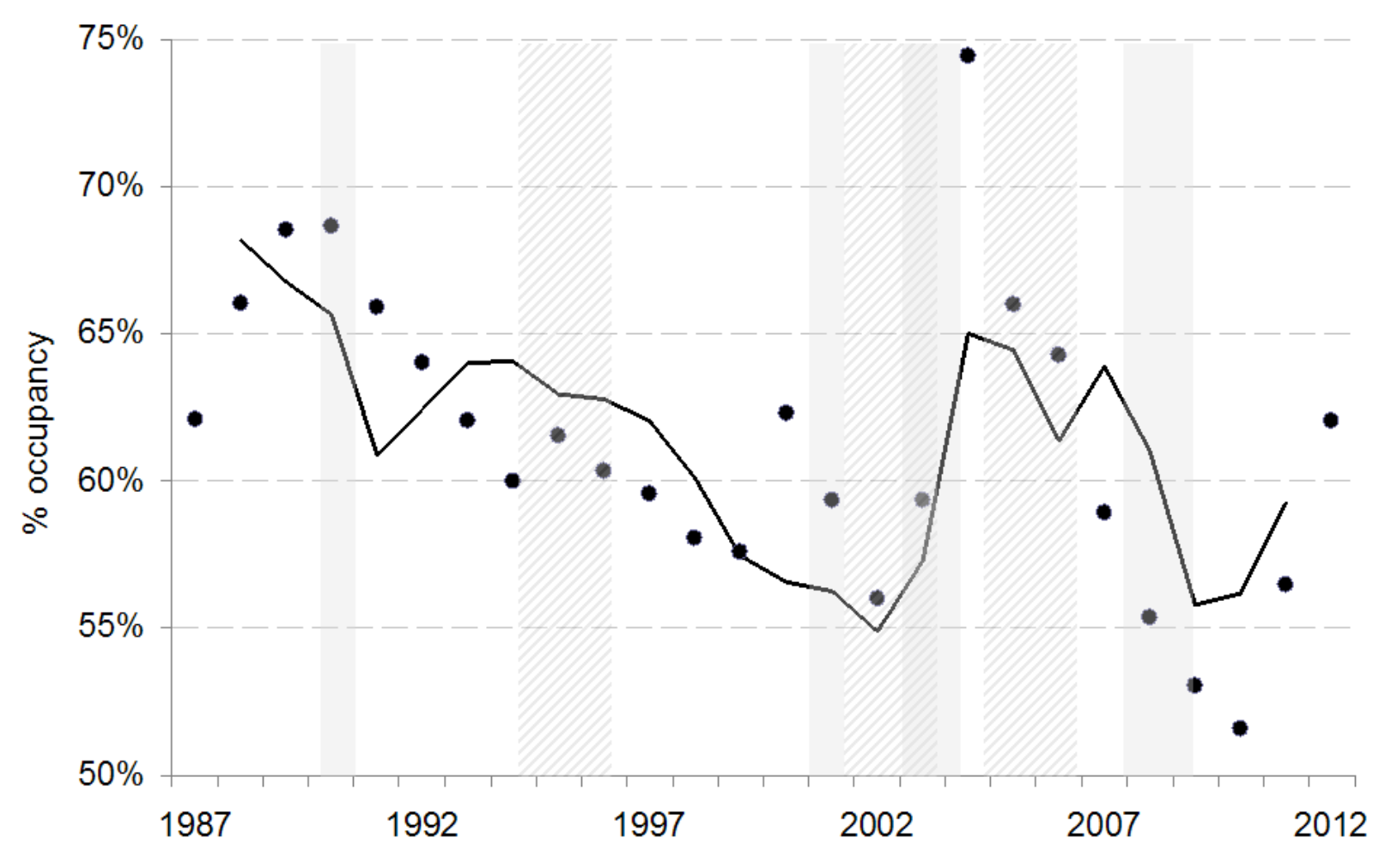


Fig. 12:

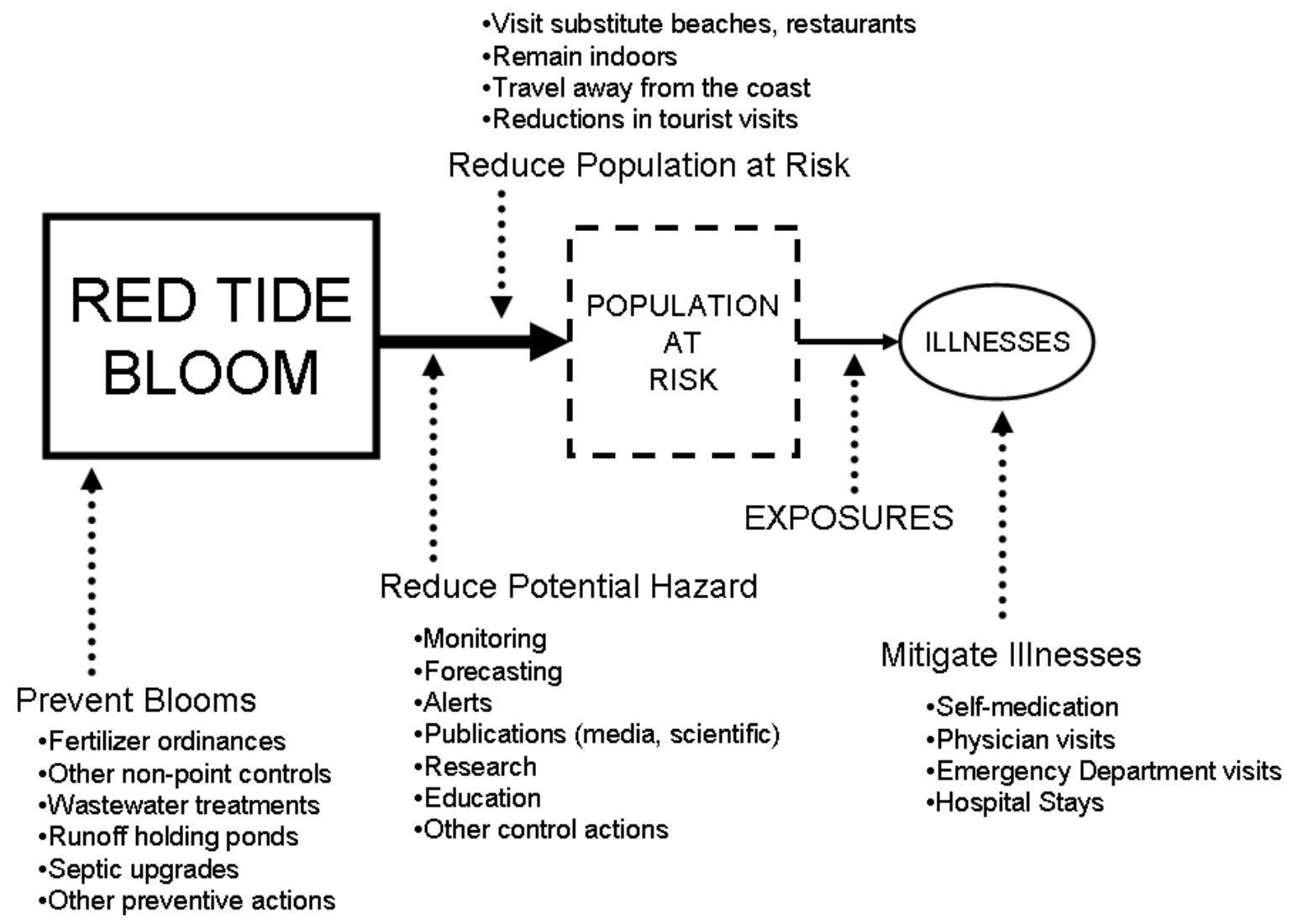


Fig. 13:

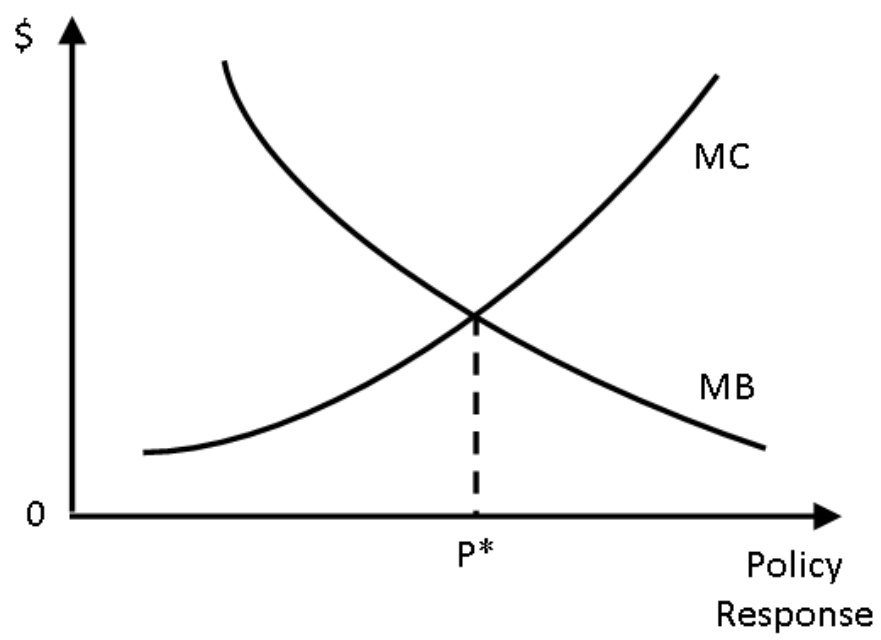


Fig. 14:

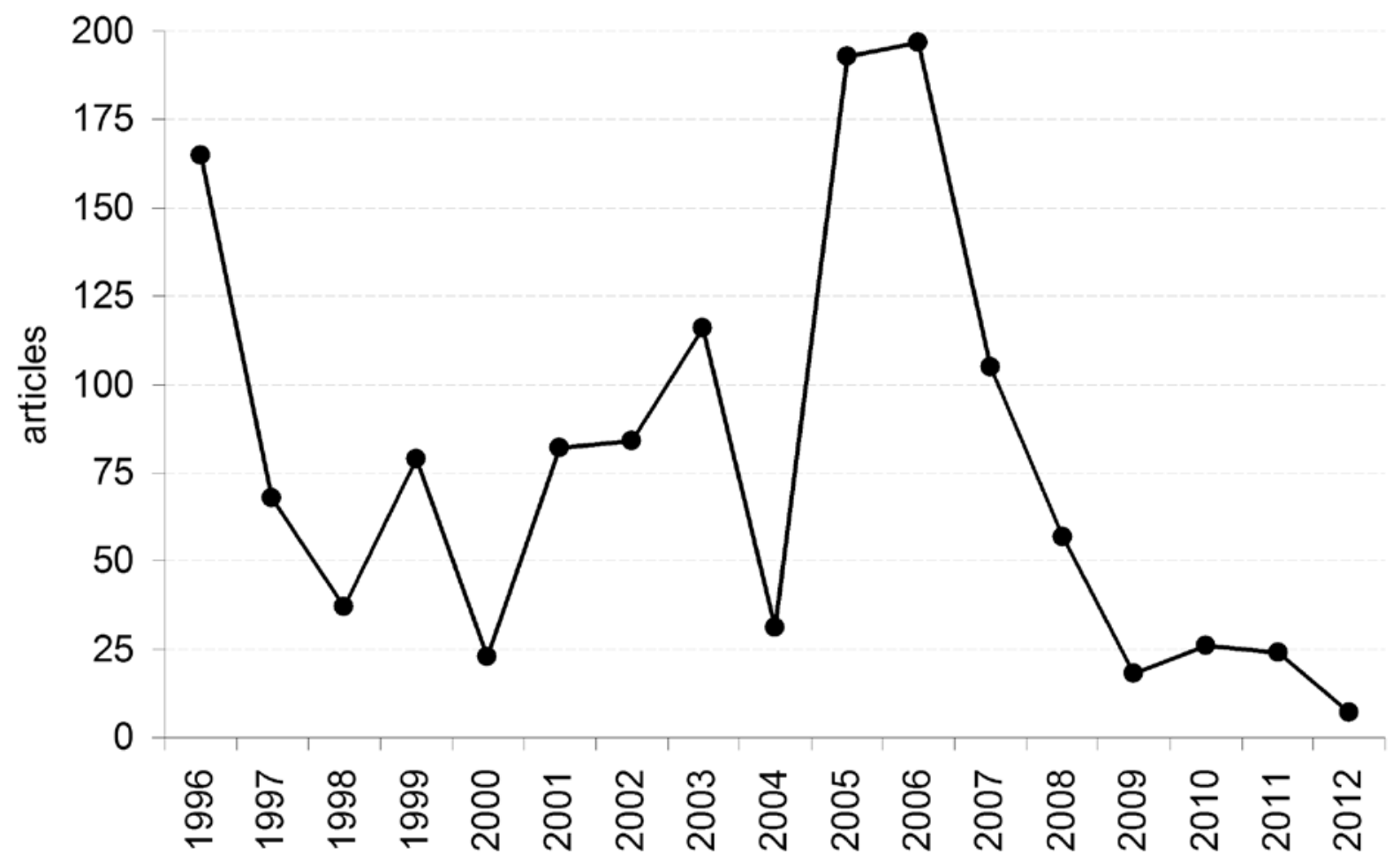


Fig. 15:

(a)

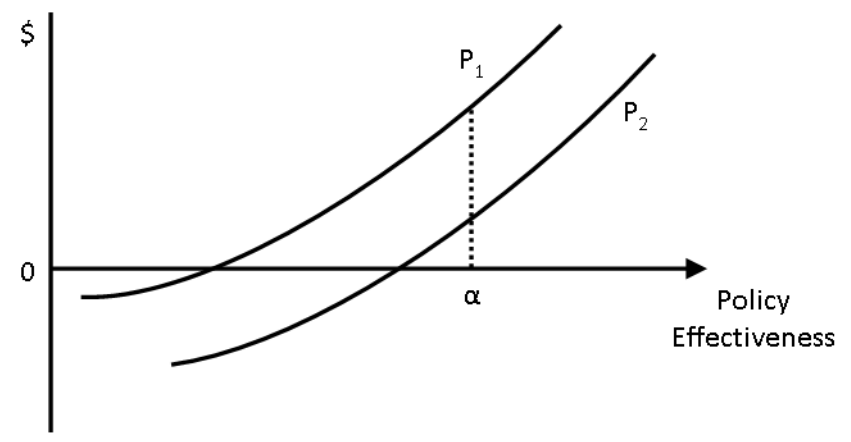

(b)

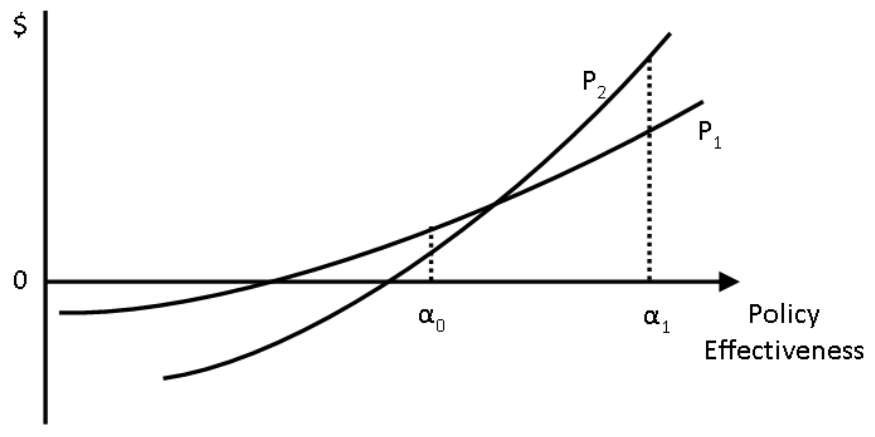


Fig. 16:

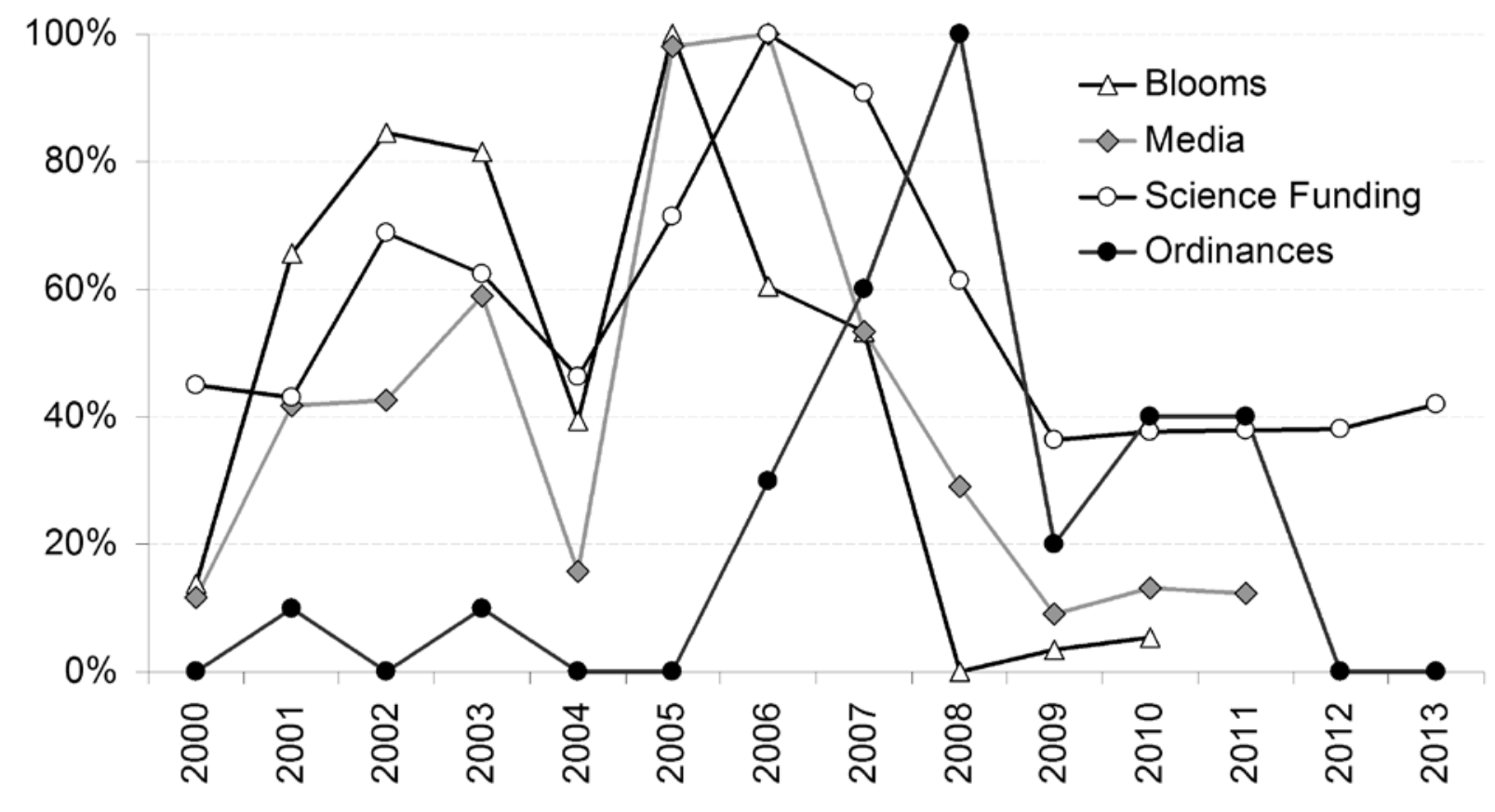

